\title{
Luteolin Inhibits Breast Cancer Development and Progression In Vitro and In Vivo by Suppressing Notch Signaling and Regulating MiRNAs
}

\author{
Da-Wei Sun ${ }^{\mathrm{a}}$ He-Da Zhang ${ }^{\mathrm{b}}$ Ling Mao ${ }^{c}$ Chang-Fei Mao ${ }^{d}$ Wei Chen ${ }^{\mathrm{b}}$ Meng Cuie \\ Rong Ma ${ }^{f}$ Hai-Xia Cao ${ }^{f}$ Chang-Weng Jing ${ }^{f}$ Zhuo Wang ${ }^{f}$ Jian-Zhong $\mathrm{Wu}^{f}$ \\ Jin-Hai Tanga,g

\begin{abstract}
${ }^{a}$ Nanjing University of Chinese Medicine, Nanjing, 'bGaduate School of Xuzhou Medical College, Xuzhou, 'Department of General Surgery, Huai'an Second People's Hospital, Xuzhou Medical College, Huai'an, ${ }^{\mathrm{T} T h e}$ Fourth Clinical College of Nanjing Medical University, Nanjing, ${ }^{e}$ Operation room, Jiangsu Cancer Hospital, Nanjing, 'Research Center of Clinical Oncology, Jiangsu Cancer Hospital, Nanjing, פDepartment of General Surgery, Jiangsu Cancer Hospital, Nanjing, China
\end{abstract}

\section{Key Words}

Luteolin • Notch signaling $\bullet$ miRNA $・$ Breast cancer

\begin{abstract}
Background/Aims: This study aims to investigate the effect of Luteolin on breast cancer in vitro and in vivo and the interaction between miRNAs and Notch signaling after Luteolin intervention, and illustrates the possible underlying mechanism and regulation loop. Methods: Cell growth/survival assays and cell cycle analyses were performed to evaluate cell survival in vitro. Scratch tests, cell invasion assays and tube formation assays were carried out to analyze cell viability and identify the impact of Luteolin on angiogenesis. Critical components in the Notch pathway including proteins and mRNAs were detected by Western blotting analyses, ELISA assays and real-time reverse transcription-polymerase chain reaction. Matrix metalloproteinases activity was evaluated by gelatin zymography analyses. MiRNAs were analyzed by miRNA expression assays. After MDA-MB-231 cells were separately transfected with Notch-1 siRNA/cDNA and miRNA mimics, the above assays were also carried out to examine potential tumor cell changes. Xenograft models were applied to evaluate the treatment potency of Luteolin in breast cancer. Results: Luteolin significantly inhibited breast cancer cell survival, cell cycle, tube formation and the expression of Notch signaling-related proteins and mRNAs, and regulated miRNAs. After introducing Notch-1 siRNA and miRNA mimics, MDA-MB-231 cells presented with changes in miRNA levels, reduced Notch signaling-related proteins, and decreased tumor survival, invasion and angiogenesis. Conclusion: Luteolin inhibits Notch signaling by regulating miRNAs. However, the effect of miRNAs on the Notch pathway could be either Luteolin-dependent or Luteolin-independent. Furthermore, Notch-1 alteration may inversely change miRNAs levels. Our data demonstrates that Luteolin, miRNAs and the Notch pathway are critical in breast cancer development and prognosis.
\end{abstract}

Copyright (c) 2015 S. Karger AG, Basel 


\section{Cellular Physiology Cell Physiol Biochem 2015;37:1693-1711

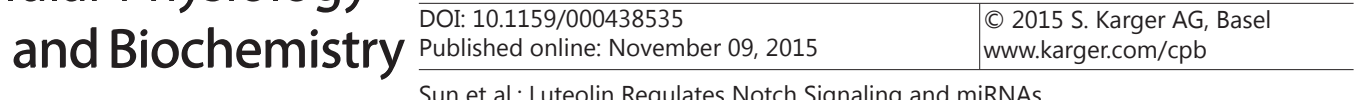

\section{Introduction}

Breast cancer is the most prevalent cancer in females in the United States, and it was the leading cause of cancer death in women aged 20 to 59 years old, according to Cancer Statistics, 2014 [1]. In the past decades, developments in cancer treatment have significantly changed the life spectrum and improved the quality of life of breast cancer patients. However, a respectable number of patients diagnosed with metastatic disease at the time of initial visit continue to suffer from poor clinical outcomes. Therefore, these patients require more efficient and specific treatments to achieve better cancer control and improve survival. Among all strategies, therapeutic options that target critical components in cancer evolvement and metastasis signaling have great potentials.

Notch signaling plays a pivotal role in cell-fate determination processes including cell maintenance, differentiation, proliferation and apoptosis; thus, it is important in breast cancer development. A previous publication reported that the combination of Notch ligands and receptors in adjacent cells could activate proteolysis of the former, which is mediated by $\gamma$-secretase. This process releases the Notch intracellular domain (ICD) into the nucleus, and therefore, causes the activation of HES/HEY; which maintains stem cells by inhibiting cell differentiation [2]. A few other studies have also revealed an uncontrollable Notch receptor expression in human solid tumors such as hepatocellular carcinoma, prostate cancer, cervical cancer, non-small cell lung cancer, and osteosarcoma [3-8]. All above evidences suggest that Notch signaling could potentially contribute to the development and progression of breast cancer, and the inhibition of the Notch pathway could possibly be a valuable treatment strategy.

Recently, there has been increasing interest in microRNAs (miRNAs), which are short non-coding single-stranded RNAs that suppress target homologous mRNA translation by base pair binding to their 3' untranslated region and inhibit protein synthesis [9]. MiRNAs are implicated in various cellular processes such as cell metabolism and immunoregulation, and have been revealed to be abnormally expressed in different kinds of tumors. Therefore, they are commonly applied in cancer diagnosis, treatment and prognosis [10]. Wang et al. reported that cross-talk between miRNAs and Notch signaling contributed to tumor development [11]. Meanwhile, other studies have also provided evidence that miR-34a was involved in regulating the $p 53$ and Notch pathway $[12,13]$. The above results suggests a possible mechanism in Notch signaling regulation through miRNAs, and provides justification in investigating new therapeutic targets that aim at Notch signaling and the downregulation of miRNAs for breast cancer.

Luteolin was first extracted from leaves and stems of mignonette, and is classified as a non-toxic flavonoid compound. Cardiovascular protection, immune system stimulation, anti-oxidant, anti-inflammatory and anti-carcinogenesis capacities of Luteolin have been identified in previous publications [14, 15]. Selvendiran et al. [15] reported that Luteolin significantly altered the expression of key components in tumor cell metabolism pathways, introducing cell cycle inhibition and apoptosis in vitro; and thus, achieving anticancer effects. Other studies have also addressed that Luteolin could suppress vascular formation by downregulating vascular endothelial growth factor (VEGF) mRNA levels and inhibiting extracellular matrix remodeling by inactivating matrix metalloproteinases (MMPs) $[16,17]$. Our preliminary data revealed that Luteolin has a potential of inhibiting breast cancer cells by altering the expression of Notch-1 and miR-34a. Thus, we propose that a cross-talk among Luteolin, the Notch pathway and miRNAs could exist; and that this network contributes to the regulation of breast cancer development and prognosis. In the present study, we evaluated the ability of Luteolin in modulating breast cancer cell survival, migration, invasion and vascular formation. Furthermore, we investigated the interaction between miRNAs and Notch signaling after Luteolin intervention, and illustrated their possible underlying mechanism and regulation loop.

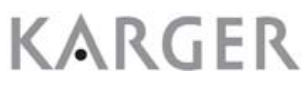




\section{Cellular Physiology Cell Physiol Biochem 2015;37:1693-1711 \begin{tabular}{ll|l} 
and Biochemistry $10.1159 / 000438535$ & Published online: November 09, 2015 & $\begin{array}{l}\text { ○ 2015 S. Karger AG, Basel } \\
\text { www.karger.com/cpb }\end{array}$ \\
\cline { 2 - 3 }
\end{tabular} Sun et al.: Luteolin Regulates Notch Signaling and miRNAs}

\section{Materials and Methods}

\section{Cell culture and experimental reagents}

MDA-MB-231 and MCF-7 human breast cancer cells (both preserved in our laboratory, Shanghai cell bank of Chinese Academy of Science) and human umbilical vein endothelium cells (HUVEC, ATCC) were cultured in Dulbecco's modified Eagle's medium-high glucose (DMEM-high glucose; KeyGen BioTECH, Nanjing, China) with $10 \%$ fetal bovine serum (FBS; Gibco, New Zealand) and $5 \% \mathrm{CO}_{2}$ at $37^{\circ} \mathrm{C}$. The following materials were applied in this study: Luteolin (Xi'an Helin Bio-technique Co. Ltd., Xian, China); dimethyl sulfoxide (DMSO; Sigma, St. Louise, USA); Cell Counting Kit-8 (CCK8; Dojindo Molecular Technologies Inc., Japan); TRIzol reagent (catalog number: 15596-026, Invitrogen, Carlsbad, USA); real-time reverse transcription-polymerase chain reaction (RT-PCR) kit (Takara Bio Inc., Japan); anti-Notch-1 intracellular domain (ICD), anti-Hes-1, anti-Hey-1, anti-Hey-2 and Cyclin D1 primary antibodies (Santa Cruz, CA, USA); anti-VEGF, anti-MMP-2 and anti-MMP-9 primary antibodies (Cell Signaling Technology, Beverly, USA); anti-Notch-1 secondary antibody (Abcam, Cambridge, MA, USA); anti-Hes-1, anti-Hey-1 and anti-Hey-2 secondary antibodies (Santa Cruz, CA, USA); Cyclin D1, anti-VEGF, anti-MMP-2 and anti-MMP-9 secondary antibodies (RayBiotech, Atlanta, USA). All reagents not mentioned above were purchased from Sigma, St. Louise, USA.

\section{Cell growth and survival assays}

Logarithmic phase MDA-MB-231 and MCF-7 cells were seeded in 96-well plates (5,000-7,000 cells/ well) and treated with Luteolin (25, 50 and $100 \mu \mathrm{mol} / \mathrm{L})$ for 24 or 48 hours [18]. Then, the media was discarded, $10 \mu \mathrm{L}$ of CCK8 was submitted into each well, incubated with $5 \% \mathrm{CO}_{2}$ at $37^{\circ} \mathrm{C}$ for another two hours, and light absorbance was measured at $450 \mathrm{~nm}$. Negative control cells were cultured in DMEM-high glucose with $0.1 \%$ DMSO and underwent the same assay protocols as mentioned above.

\section{Cell cycle analyses}

Logarithmic phase MDA-MB-231 and MCF-7 cells cultured with Luteolin (25, 50 and $100 \mu \mathrm{mol} / \mathrm{L})$ were separately collected $\left(1 \times 10^{5} \mathrm{cell} / \mathrm{s} / \mathrm{mL}\right)$, washed twice using phosphate-buffered saline (PBS), and fixed in $70 \%$ ethanol at $4^{\circ} \mathrm{C}$ for 30 minutes. Then, cells were washed with precooled PBS, and suspended in $1 \mathrm{~mL}$ of PBS and $40 \mathrm{ng}$ of propidium iodide (PI) at $37^{\circ} \mathrm{C}$ for 30 minutes. FACS Calibur flow cytometry (Becton, Dickinson and Company, CA, USA) was applied for DNA analyses.

\section{Wound-healing and cell invasion assays}

Wound-healing assay (scratch test) was described in a previous publication by Bao et al. [19]. In brief, MDA-MB-231 and MCF-7 cells were separately seeded in 6-well plates $\left(1 \times 10^{5}\right.$ cells/well). Once a single layer of cells was formed, one scratch was placed with a sterilized tip at the bottom of each well. Each sample was performed in triplicate. The above cells were then cultured in DMEM-high glucose with or without Luteolin $(50 \mu \mathrm{mol} / \mathrm{L})$ for 24 hours. The location of cells at zero and 24 hours in the scratch area was monitored with a Carl Zeiss optical microscope (Carl Zeiss Microscopy GmbH, Gottingen, Germany), and the percentage of open space covered by migrated cells was calculated [20]. Cell invasion assay was carried out using a BD BioCoat Matrigel Invasion Chamber (BD Biosciences, MA, USA) according to manufacturer's protocol [21]. MDA-MB-231 and MCF-7 cells were first cultured with Luteolin (25, 50 and $100 \mu \mathrm{mol} / \mathrm{L})$ for 24 hours. Living cells were selected (identified by trypan blue staining) and seeded in the serum-free upper chamber of the invasion system at a density of $2 \times 10^{6}$ cells $/ 200 \mu \mathrm{L}$, while $500 \mu \mathrm{L}$ of DMEM-high glucose media containing $20 \%$ FBS was added into the lower chamber. After 24 hours of incubation, cells in the upper chamber were gently removed; and cells that migrated to the lower chamber were fixed with $4 \%$ Formaldehyde solution (Xilong Chemical Co., Guangdong, China) for 30 minutes and stained with $0.2 \%$ crystal violet for 15 minutes. The ability of invasion was evaluated by cell counting in six random fields (100 $x)$ in the lower chamber. Transwell assay was performed in triplicate and the average number of migrating cells was recorded.

In vitro HUVEC tube formation assay

In order to detect the impact of Luteolin on angiogenesis, the following studies were carried out. Serumfree DMEM-high glucose was the basic medium in this part, and all cells were cultured in basic medium 


\section{Cellular Physiology Cell Physiol Biochem 2015;37:1693-1711

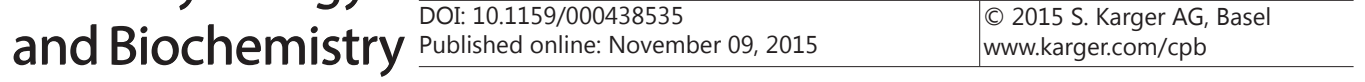 \\ Sun et al.: Luteolin Regulates Notch Signaling and miRNAs}

unless otherwise indicated. MDA-MB-231 and MCF-7 cells were pretreated with $50 \mu \mathrm{mol} / \mathrm{L}$ of Luteolin and incubated in basic medium for 24 hours. Then, the supernatant (conditional medium) was collected and stored at $-20^{\circ} \mathrm{C}$ for further use. Meanwhile, HUVECs were seeded in the Matrigel Angiogenesis System (BD Biosciences, MA, USA) at a density of $5 \times 10^{5}$ cells/well for 24 hours until approximately confluent. Then, the following five media were introduced to HUVECs separately: (1) conditional medium, (2) conditional medium with Luteolin ( $50 \mu \mathrm{mol} / \mathrm{L})$, (3) basic medium with a low dose of VEGF165 (50 ng/mL) and Luteolin (50 $\mu \mathrm{mol} / \mathrm{L}$ ), (4) positive controls: basic medium with VEGF165 (50 ng/mL) and DMSO, (5) negative controls: basic medium and DMSO. All combinations were incubated for eight hours before analyzing the impact of the supernatant and/or Luteolin on HUVEC tube formations. Five random areas in each well were imaged using a Carl Zeiss Optical microscope (Carl Zeiss Microscopy GmbH, Gottingen, Germany) and was automatically analyzed with Image-Pro Plus Software (Media Cybernetics, Inc., Rockville, MD, USA) [22].

\section{Western blotting analyses}

MDA-MB-231 and MCF-7 cells treated with Luteolin at different concentrations (25, 50 and 100 $\mu \mathrm{mol} / \mathrm{L}$ ) were lysed with RIPA buffer, and proteins were extracted for Western blotting analyses according to the following protocol. In brief, purified proteins were separated by sodium dodecyl sulfate-polyacrylamide gel electrophoresis (SDS-PAGE) and transferred onto nitrocellulose membranes. The membranes were blocked in 5\% non-fat milk for 60-120 minutes at room temperature, and incubated overnight at $4{ }^{\circ} \mathrm{C}$ with primary antibodies against Notch-1 ICD, Hes-1, Hey-1, Hey-2, Cyclin D1, VEGF, MMP-2 and MMP-9 (dilution at 1:2,000). After incubating with the corresponding secondary antibodies (dilution at 1:5,000), membranes were washed three times with TBS-Tween (50 mM of Tris, $150 \mathrm{nM}$ of NaCl, $0.05 \%$ Tween); and proteins were visualized using chemiluminescence reagents. Western blotting results were quantified using Quantity One Software (Bio-Rad Laboratories, Inc., CA, USA).

\section{Enzyme-linked immunosorbent assay (ELISA)}

MDA-MB-231 and MCF-7 cells were seeded in 6-well plates $\left(1 \times 10^{5}\right.$ cells/well) and treated with Luteolin ( 25 or $50 \mathrm{~mol} / \mathrm{L}$ ) for 48 hours. Then, the supernatant was collected and centrifuged to remove cell debris. Samples were stored at $-20^{\circ} \mathrm{C}$ for later VEGF detection using an ELISA kit (R\&D Systems, Inc., USA). Briefly, $10 \mu \mathrm{L}$ of sample and $40 \mu \mathrm{L}$ of calibrator diluent (dilution at 1:5) were added into a pre-coated 96well microplate, alongside with a VEGF standard reference $(50 \mu \mathrm{L})$ and calibrator diluent $(50 \mu \mathrm{L})$, which served as standard and blank controls, respectively. Then, the microplate was cultured at room temperature for 30 minutes and washed four times $(100 \mu \mathrm{L}$, wash buffer). Color reagent A (50 $\mu \mathrm{L})$ and B (50 $\mu \mathrm{L})$ were added into each well and incubated for 15 minutes at $37^{\circ} \mathrm{C}$, protected from light. The above samples were then submitted to a microplate reader (Synergy 2, BioTek Instruments, Winooski, USA) to determine optical density at $450 \mathrm{~nm}$.

\section{Gelatin zymography analyses}

Gelatin zymography assay was performed to evaluate the effect of Luteotin on MMP-2 and MMP-9 activity [23]. MDA-MB-231 and MCF-7 cells were cultured in serum-free DMEM-high glucose with 50 $\mu \mathrm{mol} / \mathrm{L}$ of Luteotin for 48 hours. Then, the supernatant was collected and centrifuged to remove cell debris, $25 \mu \mathrm{L}$ of the supernatant was mixed with $25 \mu \mathrm{L}$ of SDS sample buffer, and loaded onto the SDS-PAGE in running gel ( $10 \%$ polyacrylamide) containing $0.1 \%$ gelatin. After electrophoresis, the gel was washed twice with $2.5 \%$ Triton X-100 and incubated in buffer with $50 \mathrm{mmol} / \mathrm{L}$ of Tris- $\mathrm{HCl}, 5 \mathrm{mmol} / \mathrm{L}$ of $\mathrm{CaCl}_{2}$ and $0.02 \%$ Brij-35 (pH 7.6) at $37^{\circ} \mathrm{C}$ for 18 hours. Finally, clear brands suggesting proteolytic activities were revealed by staining with $0.05 \%$ Coomassie brilliant blue (KeyGen BioTech, Nanjing, China) for four hours, and destaining with $30 \%$ methanol and $10 \%$ acetic acid for 1-2 hours. Brands were qualified using G: BOX Chemi XR5 system (Syngene, MD, USA).

\section{Real-time reverse transcription-polymerase chain reaction (real-time RT-PCR)}

In order to detect Notch-1, Hes-1, Hey-1, Hey-2, VEGF, MMP-2 and MMP-9 mRNA levels before and after Luteolin treatment, we isolated total RNA from MDA-MB-231 and MCF-7 cells using a TRIzol reagent. cDNA corresponding to each protein was prepared using a real-time RT-PCR kit according to manufacturer's instructions. All sequences of primers are listed in Table 1. As an internal control, GAPDH was also amplified. The reaction system was subjected to the following cycle for 35 times with a final elongation at $72^{\circ} \mathrm{C}$ for 


\section{Cellular Physiology Cell Physiol Biochem 2015;37:1693-1711

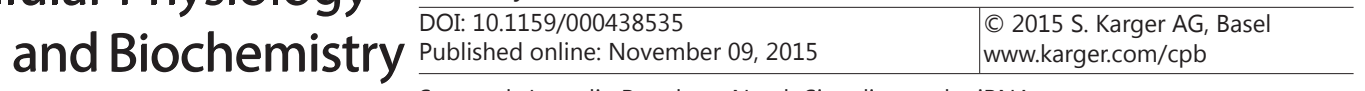 \\ Sun et al.: Luteolin Regulates Notch Signaling and miRNAs}

seven minutes: $95^{\circ} \mathrm{C}$ denaturation for five minutes, $94^{\circ} \mathrm{C}$ melting for 30 seconds, $60^{\circ} \mathrm{C}$ annealing for 60 seconds, $72^{\circ} \mathrm{C}$ extension for 30 seconds. PCR products were separated by electrophoresis in $1 \%$ agarose gels, visualized using ethidium bromide, and analyzed with an ABI Prism 7500 Sequence Detector (Applied Biosystems, Life Technologies, USA).

\section{MiRNA expression analyses}

Quantitative analyses of mature miRNAs (miR155, miR-34a, miR-181a, miR-139-5p, miR-224 and miR-246) in MDA-MB-231 cells were evaluated using an All-in-One miRNA qRT-PCR reagent kit (GeneCopoeia, Inc., MD, USA). Briefly, poly-A tails were first added to the 3 ' end of miRNAs. Then, a unique Oligo-dT Adaptor primer and M-MLV RTase reverse transcribed the poly-A miRNA. Finally,
Table 1. Primer sequences employed in real-time RT-PCR analysis

\begin{tabular}{ll}
\hline Genes & Primer $\left(5^{\prime}-3^{\prime}\right)$ \\
\hline GAPDH & F:GCACCGTCAAGGCTGAGAAC \\
& R:TGGTGAAGACGCCAGTGGA \\
Notch-1 & F:TCAGCGGGATCCACTGTGAG \\
& R:ACACAGGCAGGTGAACGAGTTG \\
Hes-1 & F:GAGCACAGAAAGTCATCAAAGC \\
& R:ATTTCCAGAATGTCCGCCTTC \\
Hey-1 & F:CGGAGAGGAATAATTGAGAAGCG \\
& R:CTTTCCCTCCTGCCGTATGC \\
Hey-2 & F:TTCAAGGCAGCTCGGTAACT \\
& R:GGGCATTTTACTTCCCCAAT \\
$M M P-2$ & F:CAGGGAATGAATACTGGATCTACT \\
& R:GCTCCAGTTAAAGGCGGCATCCAC \\
$M M P-9$ & F:GCCTGCAACGTGAACATCT \\
& R:TCAAAGACCGAGTCCAGCTT \\
\hline
\end{tabular}

miRNAs within the above products were specifically detected and quantified by SYBR Green [24].

\section{Transfection of Notch-1 siRNA and cDNA}

The siRNA applied in this study included NS 1\#, 5'-UAC AGU ACU GAC CUG UCC ACU CUGG-3' and NS 2\#, 5'-CCG CCU UUG UGC UUC UGU UCU UCGU-3'. The plasmid containing Notch-1 ICD cDNA was purchased from KeyGen BioTech, Nanjing, China. MDA-MB-231 cells were seeded in 6-well plates $\left(2 \times 10^{5}\right.$ cells/well) and incubated overnight. Notch-1 siRNA was then transfected into tumor cells, and cells with only the Lipofectamine 2000 reagent served as negative controls. MDA-MB-231 cells were also separately transfected with plasmid containing Notch-1 ICD or vector alone, and obtained with G418 selection [25, 26]. Forty-eight hours after transfection, tumor cells were collected and submitted to the following analyses: cell survival and migration assays, tube formation assays, ELISA, Gelatin zymography, Western blotting and real-time RT-PCR.

\section{Transfection of miR-34a and miR-224 mimics}

MDA-MB-231 cells were seeded in 6-well plates $\left(5 \times 10^{5}\right.$ cells/well) and incubated overnight. Then, miR-34a and miR-224 mimics (Ambion, Life Technologies, USA) were transfected into the above tumor cells using Lipofectamine 2000 reagent and incubated for 48 hours [27]. Real-time RT-PCR and Western blotting were carried out to analyze miRNA and downstream protein expression.

\section{Animal experiments}

Female BALB/c nude mice were purchased from the Experimental Animal Center of the Academy of Military Medical Sciences, China (Serial number: 0027549). All animal experiments were approved by the Institutional Review Board of Nanjing University of Chinese Medicine. BALB/c nude mice (6-8 weeks) were separately caged in a standard environment, keeping ambient temperature at $20-25^{\circ} \mathrm{C}$ with $40-70 \%$ humidity and circadian rhythm. All mice were raised with complete feed and free access to water.

Human breast cancer MDA-MB-231 cells $\left(0.1 \mathrm{~mL}, 1 \times 10^{7} / \mathrm{mL}\right)$ were subcutaneously implanted into the right axilla of 6-8 week-old female BALC/c nude mice. Maximal diameter of the tumor was evaluated with a vernier caliper. When tumors reached 50 to $70 \mathrm{~mm}$, all animals were randomly assigned into four groups with six mice in each group. Tail vein injections were performed for 14 consecutive days with the following schedule: blank control group, PBS; standard treatment group, Paclitaxel at $20 \mathrm{mg} / \mathrm{kg} / \mathrm{d}$; high dose group, Luteolin at $40 \mathrm{mg} / \mathrm{kg} / \mathrm{d}$; low dose group, Luteolin at $20 \mathrm{mg} / \mathrm{kg} / \mathrm{d}$. Diameter of the long/short axis and animal daily activity were recorded. Individual tumors were weighted at the $15^{\text {th }}$ day after all mice were scarified. Tumor growth inhibition rate $(\%)=$ (average tumor weight of treatment group - average tumor weight of control group) / average tumor weight of control group $\times 100 \%$. Tumor volume (TV) $=1 / 2$ $\mathrm{ab}^{2}$; where, a represents the long axis and b represents the short axis. Relative tumor volume (RTV) $=V_{t} /$ $\mathrm{V}_{0}$; where, $\mathrm{V}_{\mathrm{t}}$ represents the TV measured on a daily basis and $\mathrm{V}_{0}$ represents the TV measured at the day of 


\section{Cellular Physiology Cell Physiol Biochem 2015;37:1693-1711 \begin{tabular}{l|l|l} 
DOI: 10.1159/000438535 & O 2015 S. Karger AG, Basel
\end{tabular} and Biochemistry Published online: November 09, 2015 www.karger.com/cpb}

assigning groups. RTV inhibition rate $(\mathrm{T} / \mathrm{C}, \%)=\mathrm{T}_{\mathrm{RTV}} / \mathrm{C}_{\mathrm{RTV}} \times 100 \%$; where, $\mathrm{T}_{\mathrm{RTV}}$ represents the $\mathrm{RTV}$ of the treatment group and $\mathrm{C}_{\mathrm{RTV}}$ represents the RTV of the control group.

\section{Statistical analyses}

Continuous variables were recorded as mean \pm standard deviation. Student's $t$-test was carried out for comparison among groups by GraphPad StatMate (GraphPad Software Inc., CA, USA). A $P$-value $<0.05$ was considered statistically significant.

\section{Results}

Luteolin inhibited breast cancer cell survival

Luteolin suppressed the growth of both MDA-MB-231 and MCF-7 cells with a timeeffect and dose-effect relationship (Fig. 1A). Tumor cells treated with $100 \mu \mathrm{mol} / \mathrm{L}$ of Luteolin exhibited the most significant inhibition effect when compared to those treated with lower doses or with controlled DMSO. Furthermore, both MDA-MB-231 and MCF-7 cells were blocked in S phases after Luteolin treatment (Fig. 1B), demonstrating that this drug could remarkably alter tumor cell survival.

\section{Luteolin decreased breast cancer cell migration}

Wound-healing tests revealed that scratches in cells treated with Luteolin remained virtually unchanged after 24 hours, whereas cells (DMSO) in the control group almost healed from the damage (Fig. 2A). Similar results were also found in cell invasion tests; wherein, a larger number of cells migrated to the lower chamber in the control group compared with the experimental groups (Luteolin, Fig. 2B). Cell invasion tests also revealed a dose-effect

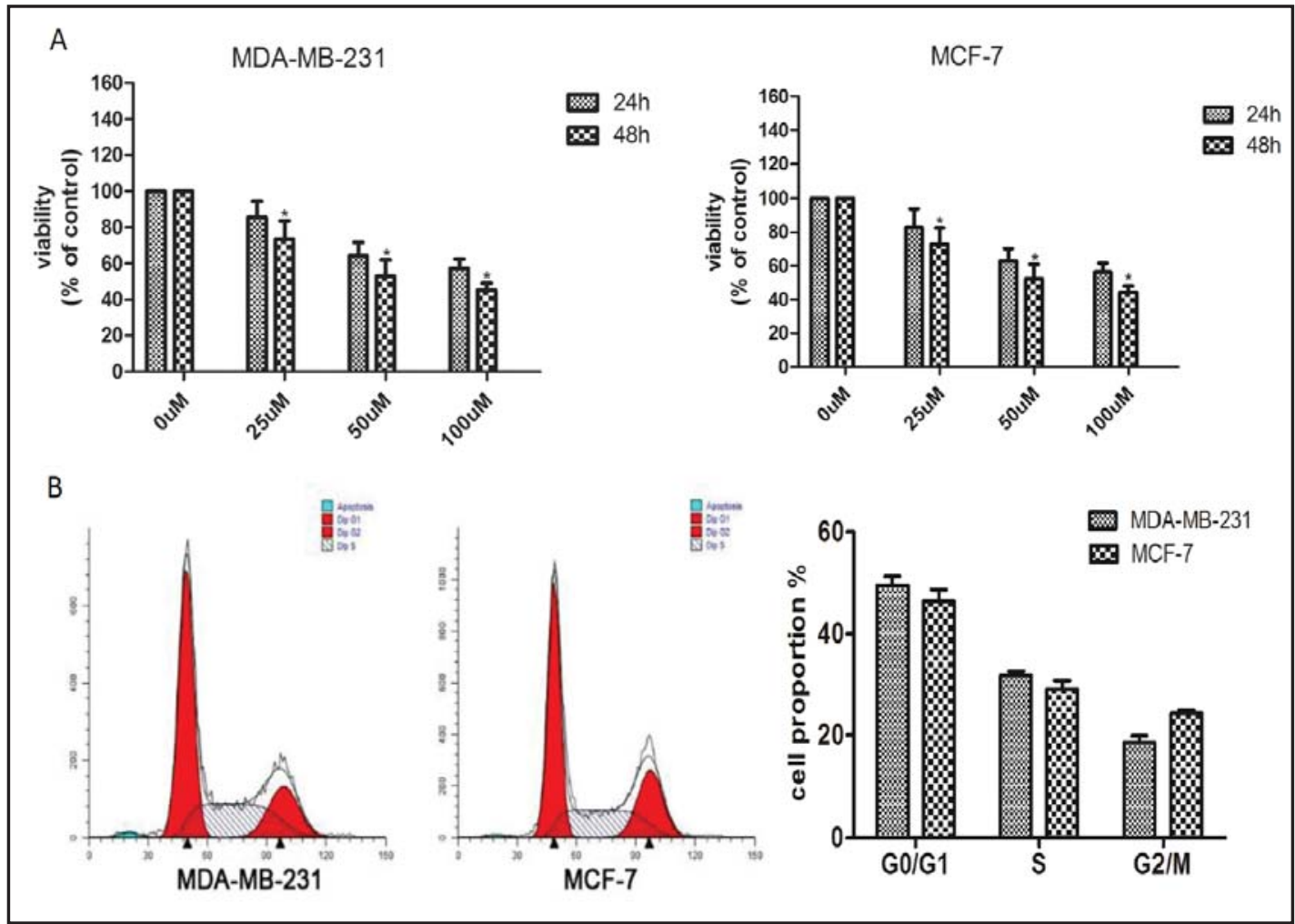

Fig. 1. (A) Cell survival analyses reveal that Luteolin inhibits breast cancer cell growth with a time-effect and dose-effect relationship; ${ }^{*} P<0.05$. (B) MDA-MB-231 and MCF-7 cells are blocked in S phases after Luteolin treatment for 48 hours. Two strains of tumor cells were employed in the experiment in triplicates. 

Cellular Physiology Cell Physiol Biochem 2015;37:1693-1711 \begin{tabular}{l|l|l|}
\hline DOI: 10.1159/000438535 & O 2015 S. Karger AG, Basel \\
\hline
\end{tabular}

Sun et al.: Luteolin Regulates Notch Signaling and miRNAs

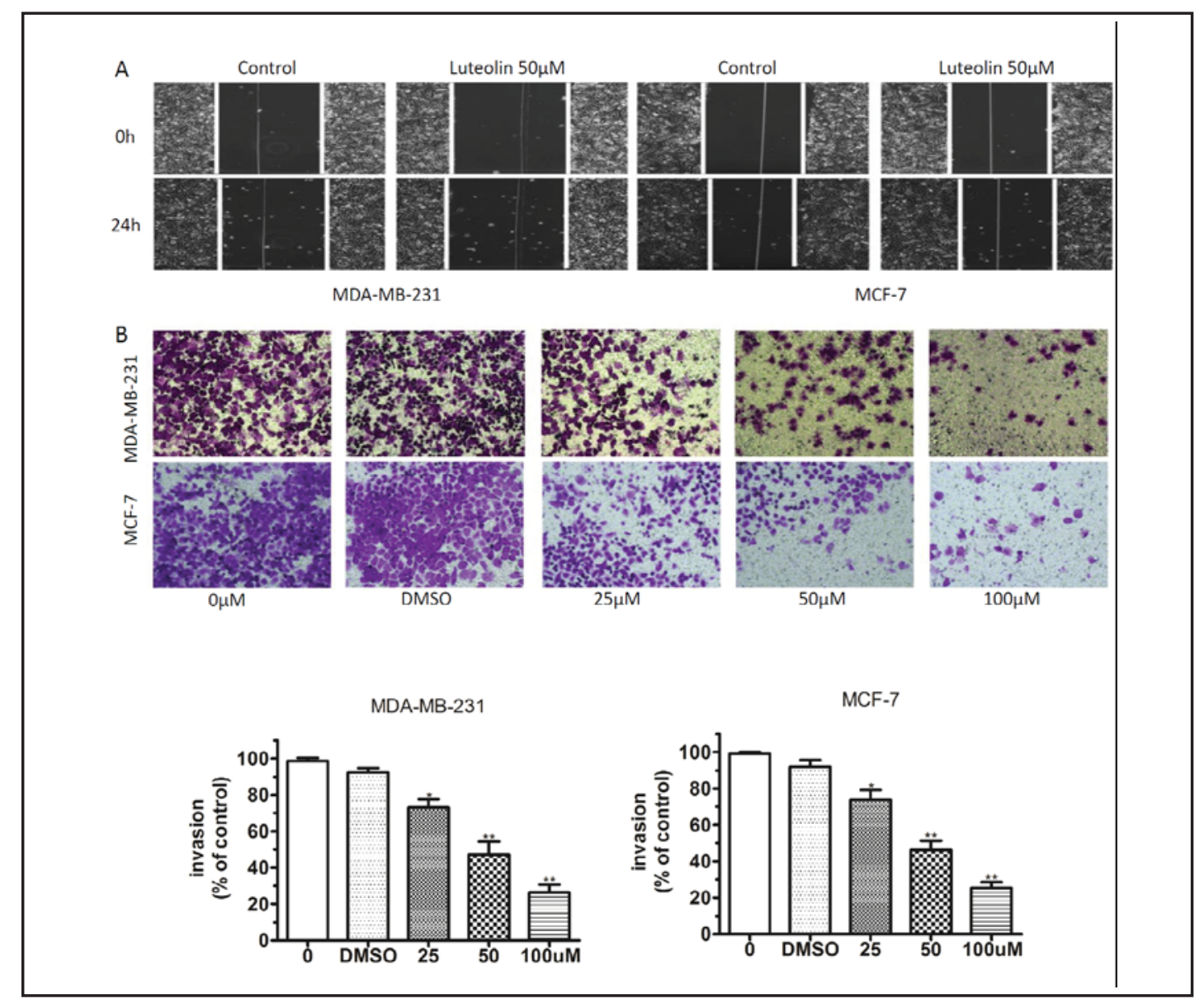

Fig. 2. Luteolin significantly suppresses recovery (A) and invasion (B) ability. ${ }^{*} P<0.05, * * P<0.01$.

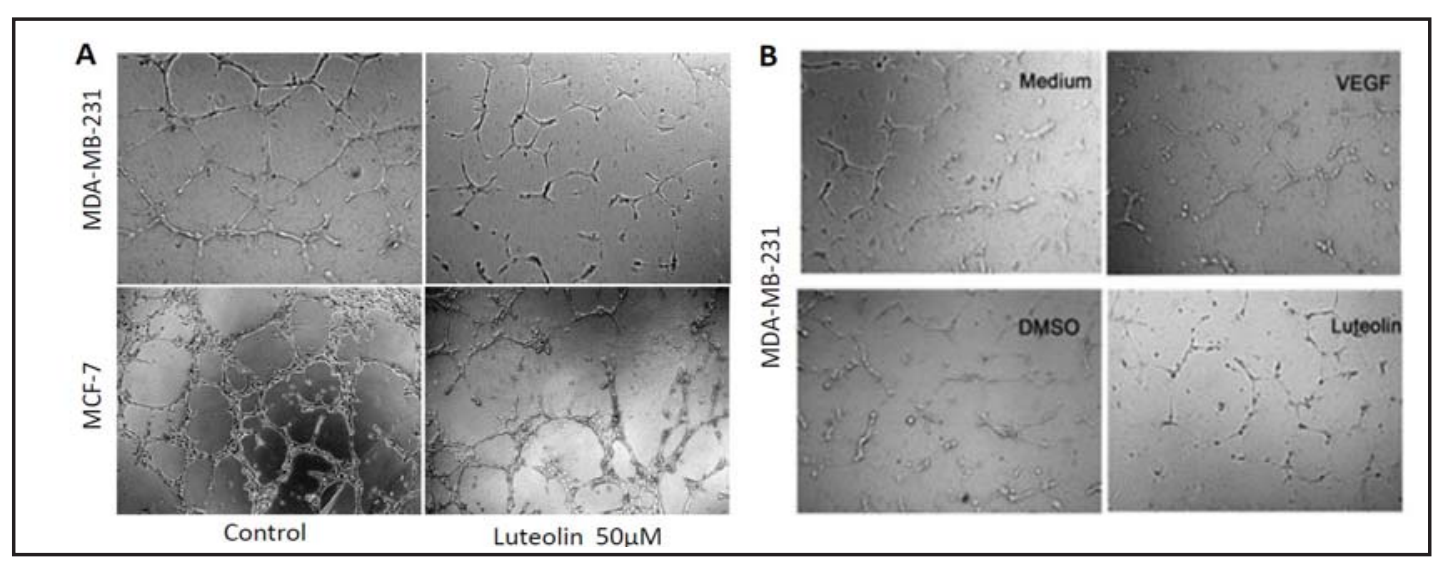

Fig. 3. (A and B) Luteolin significantly suppresses the tube formation ability of HUVECs.

relationship; wherein, cells treated with $100 \mu \mathrm{mol} / \mathrm{L}$ of Luteolin exhibited the smallest number of migrations.

Reduced HUVEC tube formations induced by decline in VEGF expression in Luteolin-treated breast cancer cells

Visible HUVEC tube formations were introduced after they were cultured in conditional medium (Fig. 3A) or treated with VEGF and DMSO, which served as positive control (Fig. 3B). However, this tube formation effect was reversed when Luteolin was applied in conditional KARGER 


\section{Cellular Physiology Cell Physiol Biochem 2015;37:1693-1711 \begin{tabular}{ll|l} 
and Biochemistry & $\begin{array}{l}\text { DOI: 10.1159/000438535 } \\
\text { Published online: November 09, } 2015\end{array}$ & $\begin{array}{l}\text { ○ 2015 S. Karger AG, Basel } \\
\text { www.karger.com/cpb }\end{array}$ \\
\hline
\end{tabular}

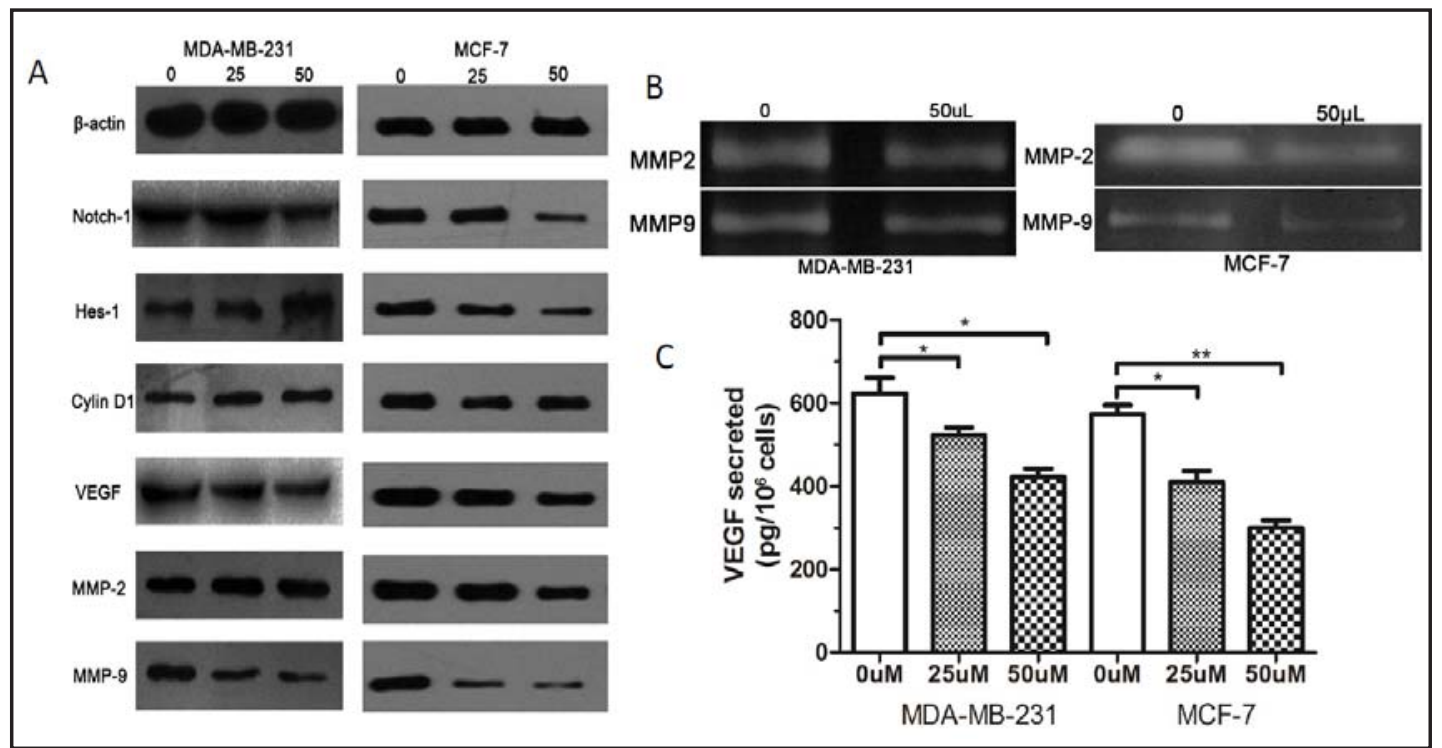

Fig. 4. (A) Luteolin significantly decreases Notch-1, Hes-1, Cyclin D1, VEGF, MMP-2 and MMP-9 protein levels. (B) VEGF, MMP-2 and MMP-9 protein activities decline. (C). Secreted VEGF was significantly lower in cells cultured with Luteolin, presenting a dose-effect relationship. ${ }^{*} P<0.05,{ }^{* *} P<0.01$.

medium (Fig. 3A, $50 \mu \mathrm{mol} / \mathrm{L}$ ). In order to clarify whether Luteolin could directly cause tube formations without the impact of breast cancer cells, $50 \mu \mathrm{mol} / \mathrm{L}$ of Luteolin with low dose VEGF were applied for HUVEC incubation. No significant change was detected after eight hours compared to HUVECs cultured with DMSO alone, which served as a negative control (Fig. 2B, Luteolin plus VEGF vs. DMSO). These results suggest that tube formation could only be achieved with the impact of breast cancer cells (conditional medium). We also detected decreased VEGF secretions in MDA-MB-231 and MCF-7 cells treated with $50 \mu \mathrm{mol} / \mathrm{L}$ of Luteolin, compared to cells treated with DMSO $(P<0.05$, Fig. 4C), illustrating that reduced tube formations were induced by the decline in VEGF expression in Luteolin-treated breast cancer cells.

Luteolin reduced Notch-1, Hes-1, Hey, VEGF, Cyclin D1 and MMP expression in breast cancer cells

Both MDA-MB-231 and MCF-7 cells treated with $50 \mu \mathrm{mol} / \mathrm{L}$ of Luteolin for 48 hours presented decreasing expression levels of Notch-1 mRNAs, as well as its downstream genes Hes-1, Hey-1 and Hey-2; indicating that Luteolin significantly inactivated the transcription effect in the Notch pathway $(P<0.05$, Fig. 5). Similar results were also detected in Western blotting; wherein, Notch-1, Hes-1 and Cyclin D1 protein levels were lower in cells treated with Luteolin, suggesting that Luteolin may also alter protein expression in Notch signaling (Fig. 4A).

Real-time RT-PCR and Western blotting revealed a remarkable decline in VEGF, MMP2 and MMP-9 mRNAs $(P<0.05)$, as well as in VEGF, MMP- 2 and MMP-9 proteins in cancer cells; indicating that Luteolin plays an important role in both tumor cell growth and matrix invasion (Fig. 5 and 4A). Luteolin helped to decrease MMP-2 and MMP-9 protein activity, as indicated in the gelatin zymography assay; wherein, Luteolin-treated cells presented a lower gray scale (Fig. 4B). Secreted VEGF in the supernatant was also lower in cells cultured with Luteolin, presenting a dose-effect relationship in ELISA assays $(P<0.05$, Fig. 4C).

MiRNA expression in Luteolin-treated breast cancer cells

MiR-181a, miR-139-5p, miR-224 and miR-246 expression levels in both MDA-MB-231 and MCF-7 cells were significantly enhanced after Luteolin treatment, while miR-155 level decreased $(P<0.05$, Fig. 6). MiR-34a expression only increased in Luteolin-treated MDA- 


\section{Cellular Physiology Cell Physiol Biochem 2015;37:1693-1711 \begin{tabular}{l|l|l}
\hline DOI: 10.1159/000438535 & (C) 2015 S. Karger AG, Basel
\end{tabular} \begin{tabular}{l|l} 
and Biochemistry Published online: November 09, 2015 & www.karger.com/cpb \\
\hline
\end{tabular}

Fig. 5. Luteolin inhibits Notch-1, Hes-1, Hey-1, Hey2, VEGF, MMP-2 and $M M P-9 \mathrm{mRNA}$ expression levels. $* P<0.05,{ }^{* *} P<$ 0.01 .
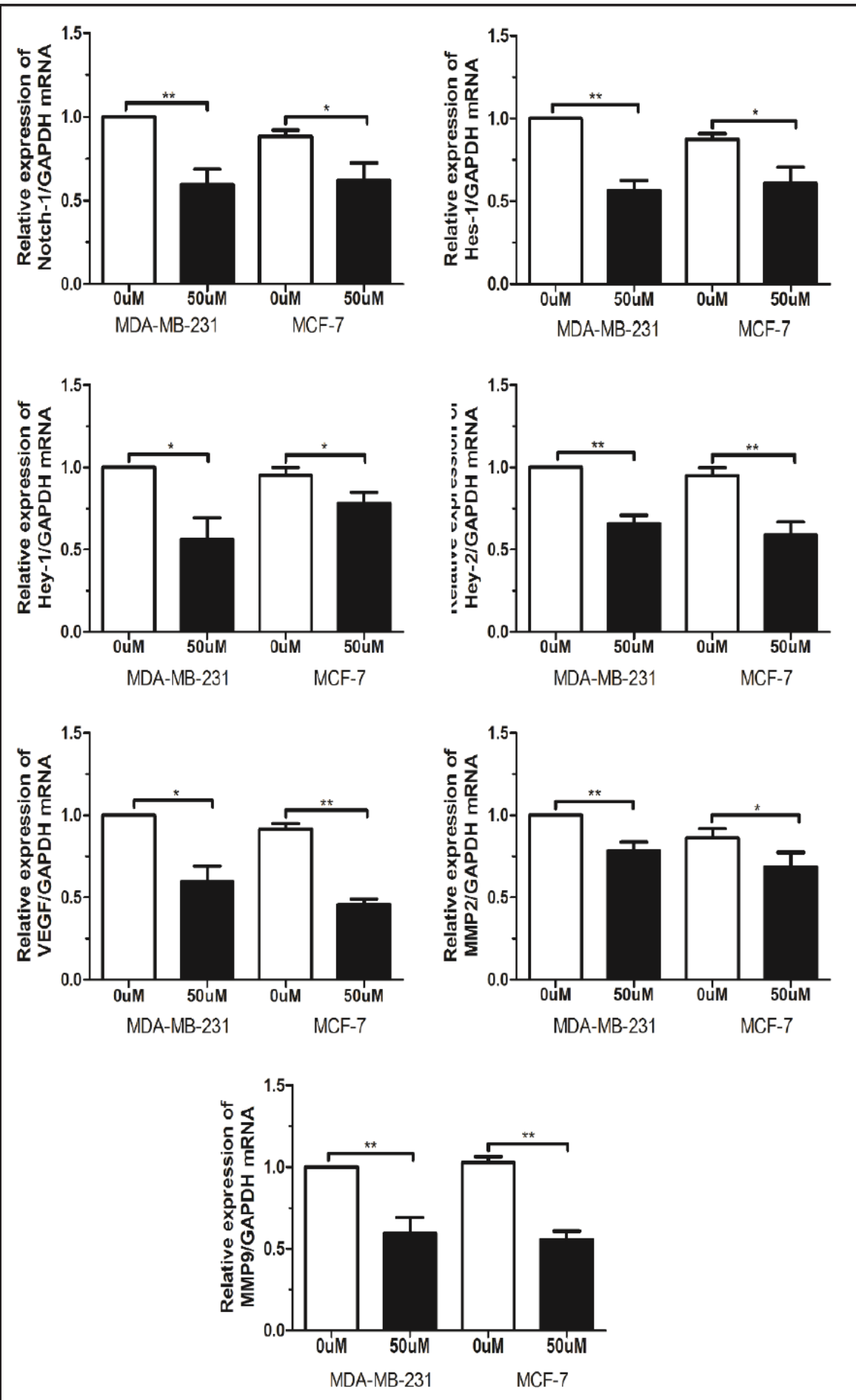

MB-231 cells $(P<0.05$, Fig. 6). The above results suggest that Luteolin distinctively altered miRNA levels in breast cancer cells.

Effect of Notch-1 silence on miRNA levels in breast cancer cells

After Notch-1 siRNA transfection, MDA-MB-231 cells presented increased miR-34a, miR-181a, miR-139-5p, miR-224 and miR-246 expression levels, while exhibiting decreased miR-155 levels (Fig. 7). The above results were similar to MDA-MB-231 cells treated with Luteolin (Fig. 6). 


\section{Cellular Physiology Cell Physiol Biochem 2015;37:1693-1711 \begin{tabular}{l|l|l}
\hline DOI: 10.1159/000438535 & (c) 2015 S. Karger AG, Basel
\end{tabular} \begin{tabular}{l|l} 
and Biochemistry Published online: November 09, 2015 & www.karger.com/cpb \\
\hline
\end{tabular}

Fig. 6. After Luteolin treatment, miR-181a, miR-139-5p, miR224 and miR-246 expression levels in both MDA-MB-231 and MCF-7 cells are significantly enhanced; while miR155 level decreases. MiR-34a level is only enhanced in MDA-MB-231 cells. ${ }^{*} P<0.05,{ }^{* *} P<0.01$
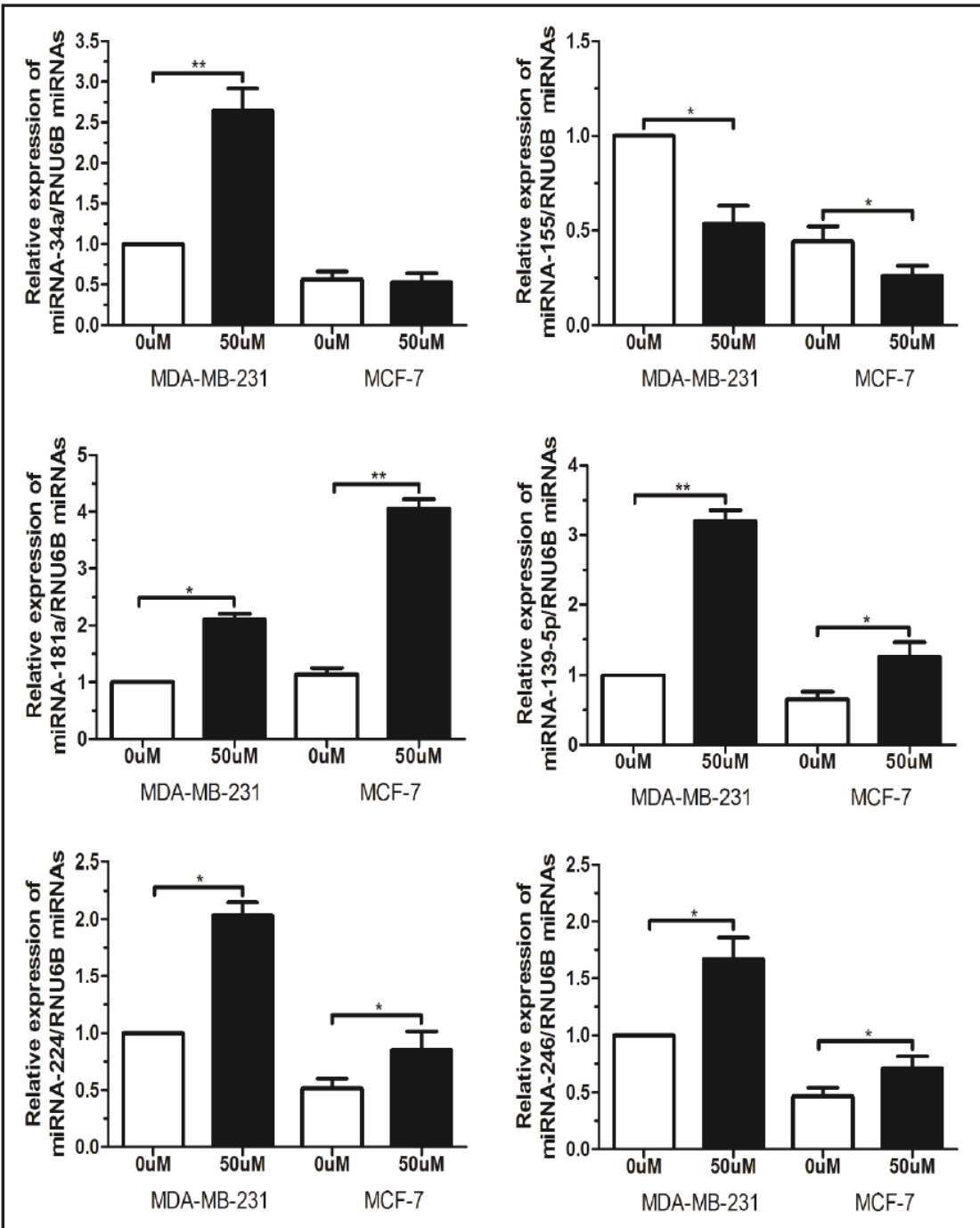

Effect of Notch-1 silence and overexpression on breast cancer cell survival, invasion and angiogenesis

After Notch-1 siRNA transfection, Notch-1, Hes-1, Cyclin D1, VEGF, MMP-2 and MMP9 protein expression levels decreased in MDA-MB-231 cells (Fig. 8). Cancer cell survival, migration ability and HUVEC tube formations were also inhibited with the downregulation of Notch-1 introduced by siRNA transfection (Fig. 8, B-D). Moreover, these suppressive effects increased when $25 \mu \mathrm{mol} / \mathrm{L}$ of Luteolin was added to Notch-1-silenced MDA-MB-231 cells $(P<0.01$; Fig. 8, B-D). Western blotting also presented similar results; wherein, Notch-1 silencing together with Luteolin could more effectively inactivate proteins in Notch signaling (Fig. 9A). Notch-1 downregulation triggered by siRNA promoted Luteolin-induced MMP-2 and MMP-9 inactivation and low VEGF secretion (Fig. 9B).

Notch-1 ICD cDNA was successfully transfected to MDA-MB-231 cells, and these cells presented an overexpression of Notch-1 (Fig. 10A), promoting cell survival and invasion $(P<0.05$; Fig.10, B-C). Notch-1 upregulation could also suppress a Luteolin-induced inhibiting effect on cell growth and migration (Fig. 10, B-C).

MiR-34a and miR-224 regulated Notch signaling and inhibited breast cancer cell survival, migration and angiogenesis

MiR-34a and miR-224 mimics were successfully transfected into MDA-MB-231 cells, and high miRNA expression levels were detected compared to blank control $(P<0.05$, Fig. 


\section{Cellular Physiology Cell Physiol Biochem 2015;37:1693-1711 \begin{tabular}{ll|l} 
and Biochemistry & $\begin{array}{l}\text { DOI: 10.1159/000438535 } \\
\text { Published online: November 09, 2015 }\end{array}$ & $\begin{array}{l}\text { O 2015 S. Karger AG, Basel } \\
\text { www.karger.com/cpb }\end{array}$ \\
\cline { 2 - 3 }
\end{tabular}
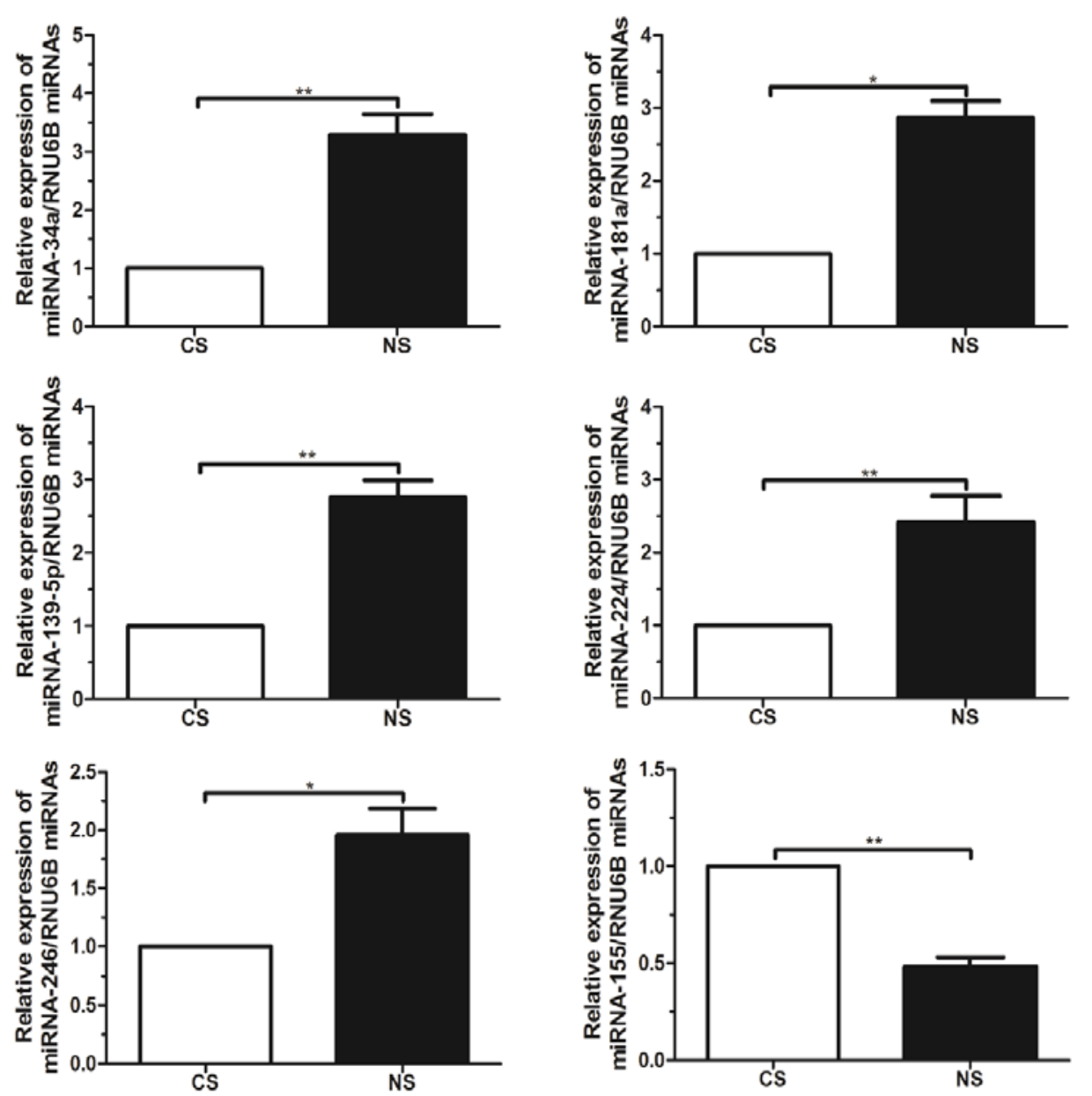

Fig. 7. After transfecting with Notch-1 siRNA, MDA-MB-231 cells present increased miR-34a, miR-181a, miR-139-5p, miR-224 and miR-246 expression levels, while exhibiting decreased miR-155 levels. ${ }^{*} P<0.05$, $* * P<0.01$.

11A). Transfected miRNAs presented inhibiting effects on Notch-1, VEGF, MMP-2 and MMP9 protein expression levels (Fig. 11A), reduced MMP-2 and MMP-9 activity, and decreased VEGF secretion in MDA-MB-231 cells (Fig. 11B). Cancer cell viability, invasion/migration ability, and HUVEC tube formations were also significantly suppressed after miR-34a or miR224 mimics were transfected into MDA-MB-231 cells (Fig. 11C).

Luteolin inhibited breast cancer xenograft growth in vivo

A subcutaneous breast cancer mouse model was successfully established. All animals were randomly assigned in four groups and were treated with PBS, Paclitaxel and different doses of Luteolin, respectively. Our results revealed that high Luteolin doses effectively inhibited tumor growth in vivo, as compared to both blank control and standard therapy groups, given that significant tumor weight and volume reduction were detected in the former (Fig. 12). High dose $(40 \mathrm{mg} / \mathrm{kg} / \mathrm{d})$ and low dose $(20 \mathrm{mg} / \mathrm{kg} / \mathrm{d})$ Luteolin groups presented RTV inhibition rates of $28.31 \%$ and $40.50 \%$, respectively; and tumor growth inhibition rates of $54.28 \%$ and $40.38 \%$, respectively. All data were statistically different from those in the blank control group $(P<0.05$, Fig. 12). In addition, none of the mice in the Luteolin groups suffered from toxic side effects such as weight loss or activity reduction, demonstrating that Luteolin could significantly change the growth profile of breast cancer in a xenograft model with no negative effect on daily animal activity. 


\section{Cellular Physiology Cell Physiol Biochem 2015;37:1693-1711

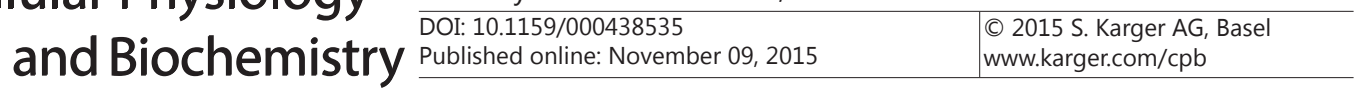

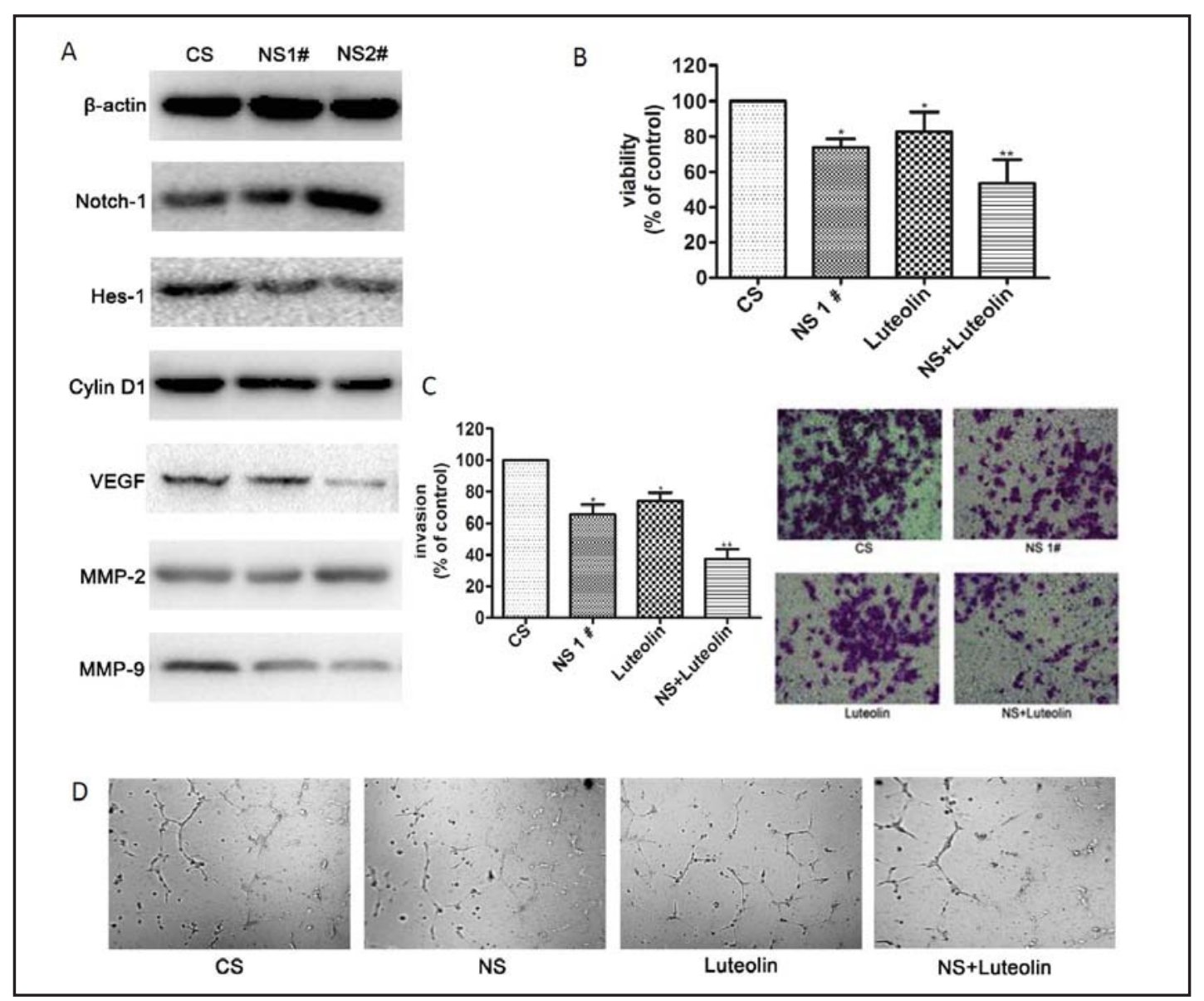

Fig. 8. Notch-1 siRNA remarkably decreases Notch-1, Hes-1, Cyclin D1, VEGF, MMP-2 and MMP-9 protein levels (A), cell survival (B), invasion (C) and tube formation (D) in MDA-MB-231 cells. Notch-1 siRNA silencing together with Luteolin significantly inhibit cell survival (B), invasion (C) and tube formation (D); CS, control siRNA; NS, Notch-1 siRNA; Luteolin, $25 \mu \mathrm{mol} / \mathrm{L}$ of Luteotin; NS + Luteolin, Notch-1 siRNA + 25 $\mu \mathrm{mol} / \mathrm{L}$ of Luteotin; ${ }^{*} P<0.05,{ }^{*} P<0.01$.

\section{Discussion}

In the past decades, researchers have revealed the anticancer effect of Luteolin in various kinds of tumors such as hepatocellular carcinoma, melanoma and gastric, ovarian, colorectal and breast cancers [28-31]. However, the mechanism underlying these positive results remains to be completely determined. In this study, we presented several innovative findings, supporting facts that Luteolin inhibits breast cancer cells in vitro and in vivo through Notch-1 signaling; and this suppressing effect is also regulated by miRNAs. The above results provide potential targets and new strategies for breast cancer treatment.

Abnormal activation of Notch signaling has long been recognized as a pivotal explanation for cancer survival, proliferation, invasion, migration and angiogenesis [7, 32]. Furthermore, it has been revealed that this pathway inhibits apoptosis by cross-talk with growth factorinduced cell survival in different malignancies including breast cancer [2-8, 11]. Our study is the first to demonstrate that Luteolin effectively reduced the expression and translation of Notch-1 mRNA, a key component in Notch signaling, and several downstream genes in the same pathway such as Hes-1, Hey-1, Hey-2 and Cyclin D1 mRNAs in breast cancer cells. This suppressing effect further led to decreased tumor survival, migration/invasion and HUVEC tube formation in vitro, as well as tumor inhibition in vivo. In the present study, we mainly focused on Notch-1 ICD, which has been previously identified as an active domain in the Notch-1 protein; and chose ICD specific primary antibody in Western blotting analyses to 


\section{Cellular Physiology Cell Physiol Biochem 2015;37:1693-1711 \begin{tabular}{l|l}
\hline DOI: 10.1159/000438535 & (c) 2015 S. Karger AG, Basel
\end{tabular} \begin{tabular}{l|l} 
and Biochemistry Published online: November 09, 2015 & www.karger.com/cpb \\
\hline
\end{tabular}}

A

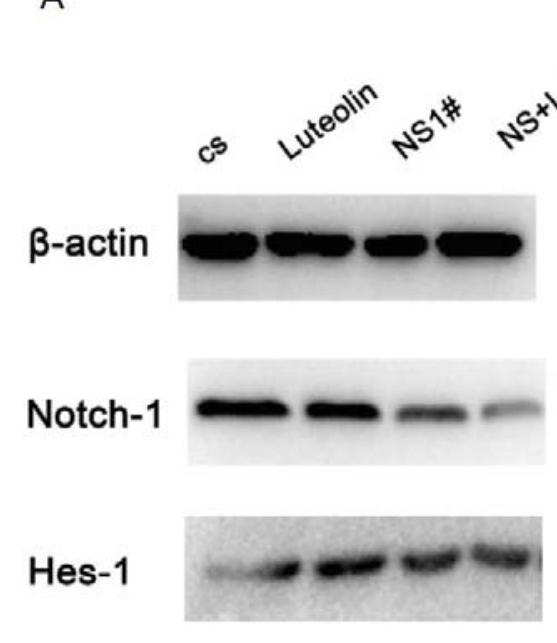

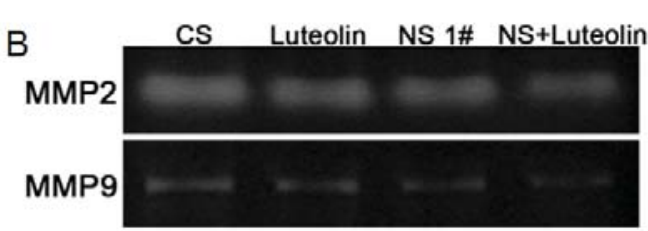

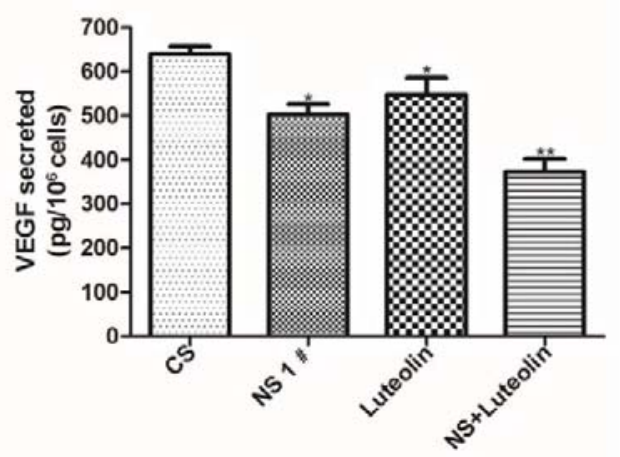

Fig. 9. Notch-1 siRNA silencing together with Luteolin significantly reduce Notch-1 and Hes-1 protein expression levels (A), inhibits MMP-2 and MMP-9 activities (B) and decrease VEGF secretion (B); CS, control siRNA; NS, Notch-1 siRNA; Luteolin, $25 \mu \mathrm{mol} / \mathrm{L}$ of Luteotin; NS+Luteolin, Notch-1 siRNA + $25 \mu \mathrm{mol} / \mathrm{L}$ of Luteotin; ${ }^{*} P<0.05,{ }^{* *} P<0.01$.

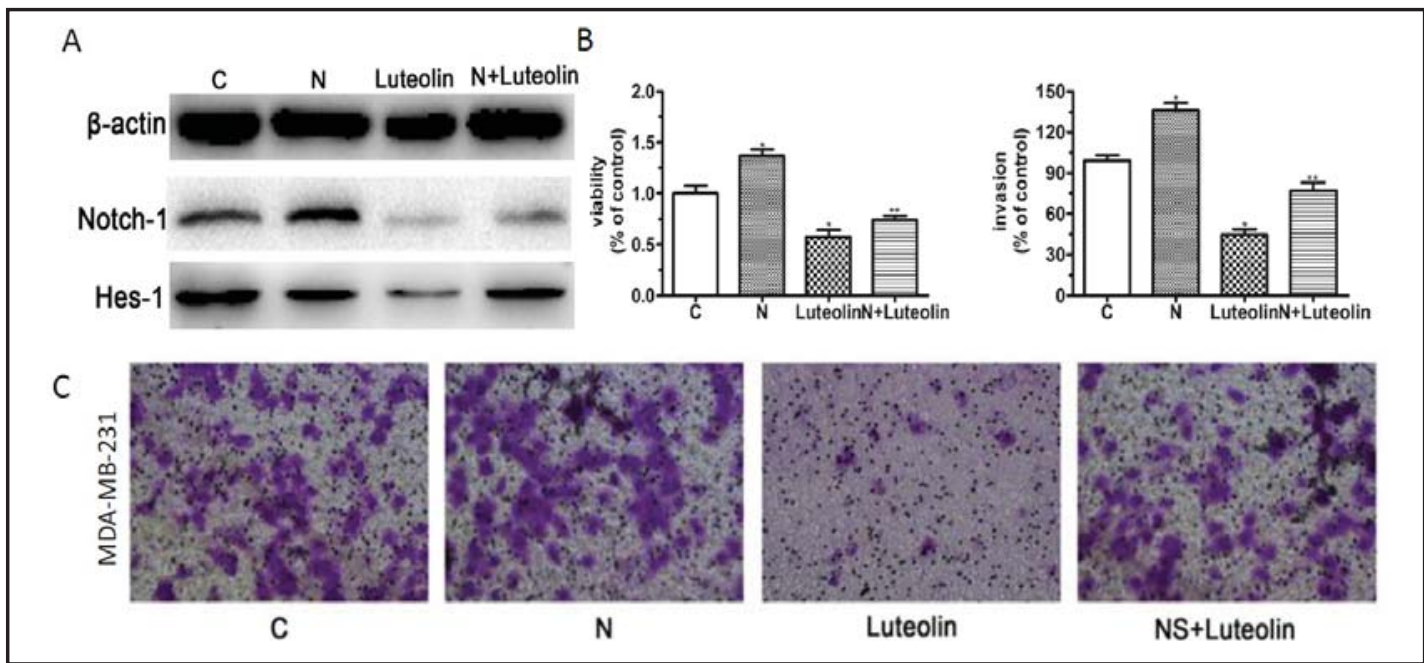

Fig. 10. (A) Notch-1 ICD cDNA was successfully transfected into MDA-MB-231 cells, and Notch-1 and Hes-1 were found to be overexpressed in these cells. Notch-1 overexpression promotes cell survival and invasion (B and C); C, control; N, Notch-1 cDNA; Luteolin, $50 \mu \mathrm{mol} / \mathrm{L}$ of Luteolin; N+Luteolin, Notch-1 cDNA+50 $\mu$ mol/L of Luteolin. ${ }^{*} P<0.05,{ }^{* *} P<0.01$.

better describe the interaction between Notch-1 and other components in the Notch pathway. Results were positive and highly suggest that Luteolin inhibits tumor activity by Notch-1 ICD suppression, leading to Notch pathway blockage. Moreover, we identified that Notch-1 silencing together with Luteolin could further enhance the efficacy of tumor inhibition, as well as key component suppression (Notch-1 and Hes-1), suggesting a better strategy for breast cancer control and treatment.

Prior publications have reported that Notch-1 activation relates to some critical factors that contribute to cell migration and regulation including VEGF, MMP-2 and MMP-9 [11, 33, $34]$. These factors were also found to directly cause tissue remodeling and angiogenesis [35, 

Cellular Physiology Cell Physiol Biochem 2015;37:1693-1711 \begin{tabular}{l|l|l}
\hline DOI: 10.1159/000438535 & (c) 2015 S. Karger AG, Basel
\end{tabular} and Biochemistry Published online: November 09, 2015 www.karger.com/cpb

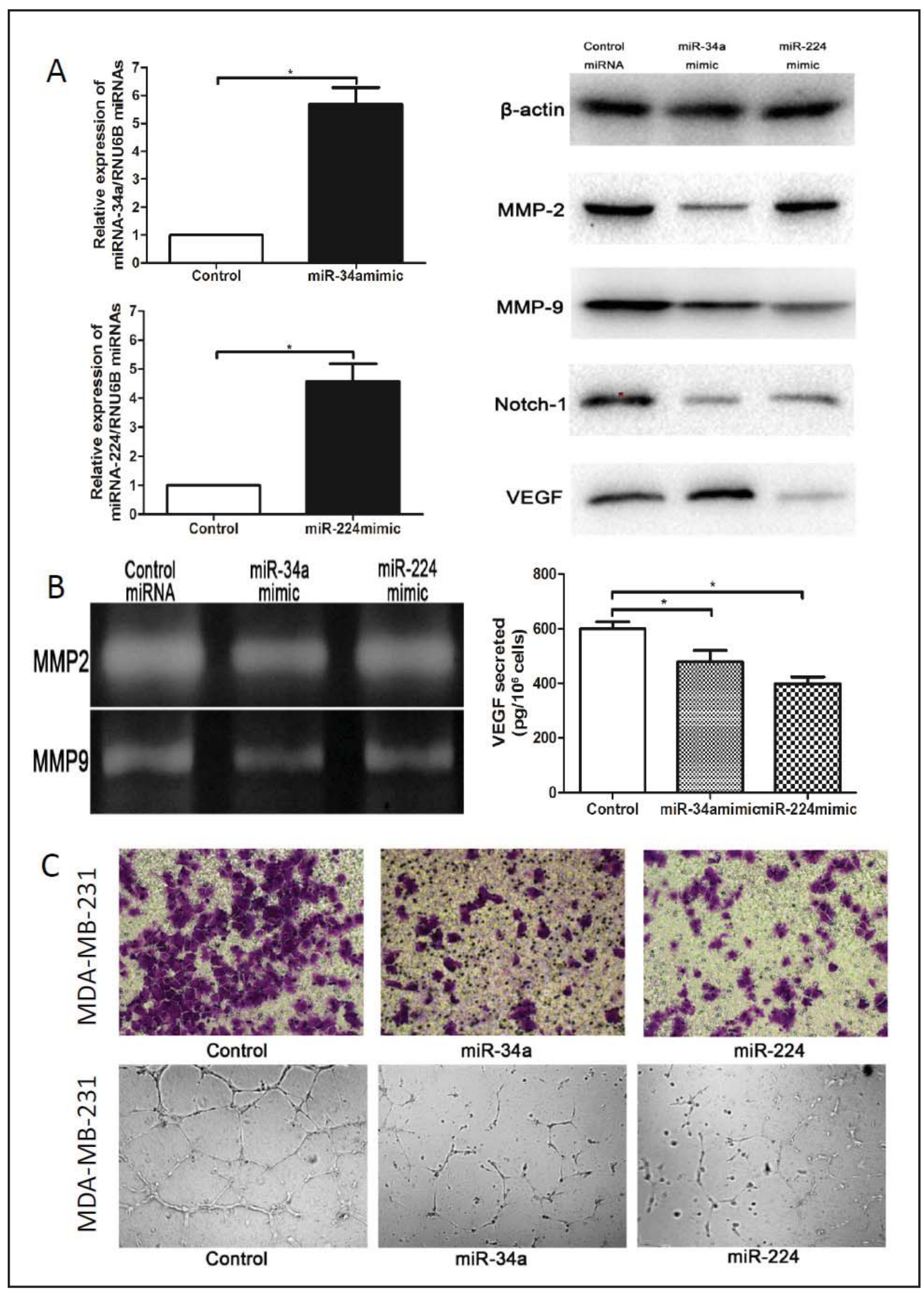

Fig. 11. (A) MiR-34a and miR-224 mimics were successfully transfected into MDA-MB-231 cells, and overexpression of corresponding miRNAs are presented. Transfected miR-34a and miR-224 mimics present inhibiting effects on Notch-1, VEGF, MMP-2 and MMP-9 protein expression levels. (B). Transfected miR34a and miR-224 mimics reduce MMP-2 and MMP-9 activities and inhibit VEGF secretion in MDA-MB-231 cells. (C). Cancer cell viability, invasion/migration ability and HUVEC tube formation were significantly suppressed after miR-34a or miR-224 transfection. ${ }^{*} P<0.05,{ }^{* *} P<0.01$.

\section{KARGER}




\section{Cellular Physiology Cell Physiol Biochem 2015;37:1693-1711 \begin{tabular}{l|l|l}
\cline { 2 - 3 } DOI: 10.1159/000438535 & (C) 2015 S. Karger AG, Basel
\end{tabular} \begin{tabular}{l|l} 
and Biochemistry Published online: November 09, 2015 & www.karger.com/cpb \\
\hline
\end{tabular}}

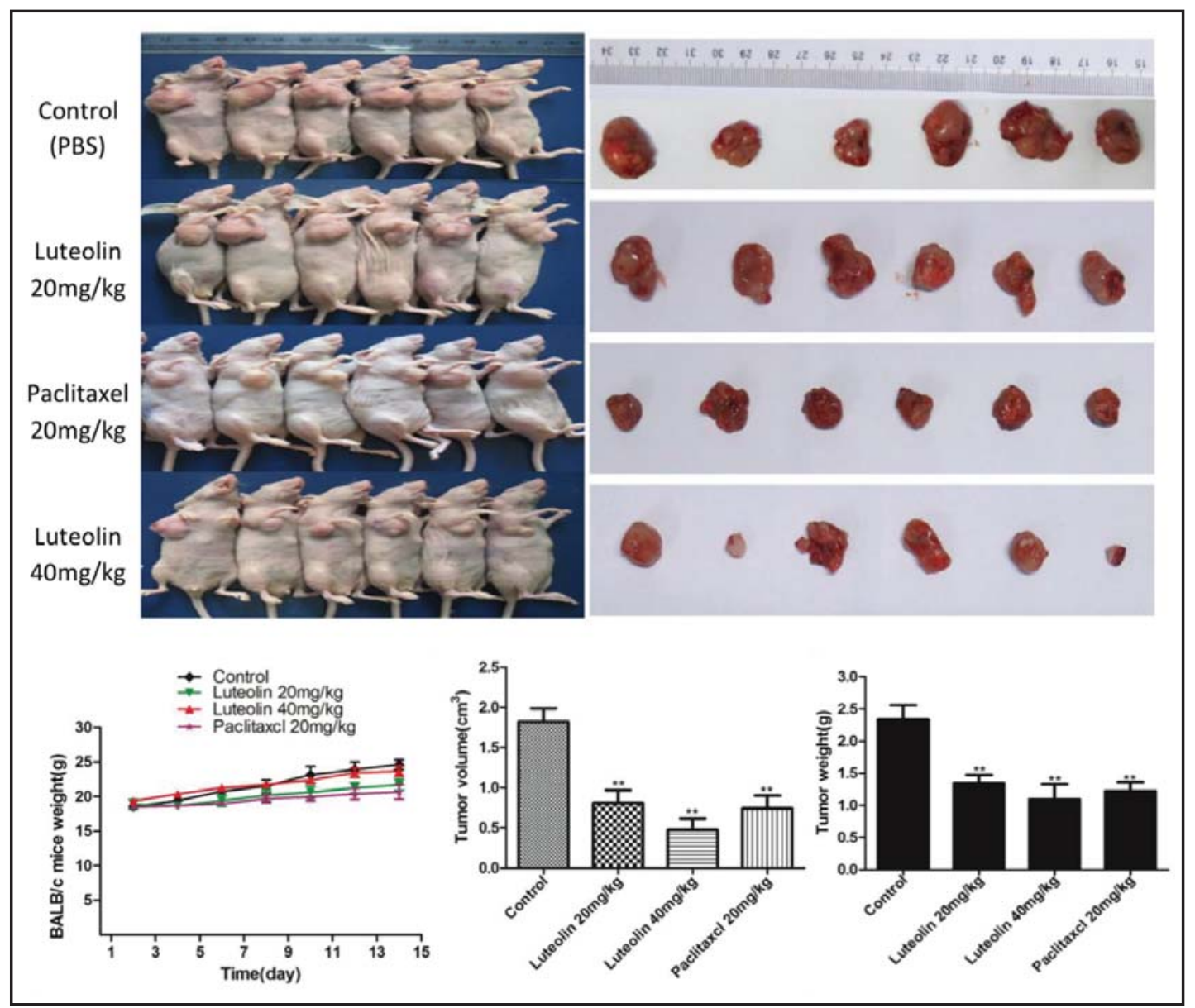

Fig. 12. In vivo study shows that a high dose of Luteolin significantly inhibited tumor weight and volume, while none of the mice suffered from weight loss. ${ }^{*} P<0.05,{ }^{* *} P<0.01$.

36]. Li et al. suggested that the suppressing effect introduced by Curcumin in Notch signaling could downregulate MMP-2 and MMP-9, leading to the inhibition of osteosarcoma [26]. In this study, we not only found that Luteolin decreased VEGF, MMP-2 and MMP-9 expression levels, but also found that MMP-2 and MMP-9 activity decreased in MDA-MB-231 cells. These suppressing effects helped to reduce angiogenesis, presenting as a decline in HUVEC tube formation in our study; and therefore, decreased the possibility of tumor invasion and migration. Notch-1 silencing provided similar results with the application of Luteolin; wherein, VEGF, MMP-2 and MMP-9 expression levels were significantly inhibited, and tumor cell survival, invasion and angiogenesis were suppressed; while the overexpression of Notch-1 induced by Notch-1 ICD cDNA transfection could lead to opposite outcomes in MDA-MB-231 cells. These evidences clearly illustrate the fact that Luteolin inhibits essential components (Notch-1, Hes-1, Hey-1, Hey-2 and Cyclin D1) in Notch signaling, resulting in VEGF and MMP downregulation; and therefore, induce decreased breast cancer cell survival, invasion, migration and angiogenesis.

MiRNA has been acknowledged to be an endogenous transcriptional regulatory factor, and is crucial in the regulation of protein synthesis and stability of mRNAs [9, 37]. Several studies have shown that miRNAs control tumor development and progression by regulating the expression and transcription of tumor-associated genes and various tumor cells that present abnormal miRNA expression [37, 38]. MiR-155 was found to be closely related to many solid tumors, and was responsible for tumor progression, compromised treatment effect and decreased survival rate [39-41]. These miRNAs also presented suppressing effects 


\section{Cellular Physiology Cell Physiol Biochem 2015;37:1693-1711 \begin{tabular}{ll|l} 
and Biochemistry & $\begin{array}{l}\text { DOI: 10.1159/000438535 } \\
\text { Published online: November 09, } 2015\end{array}$ & $\begin{array}{l}\text { C 2015 S. Karger AG, Basel } \\
\text { www.karger.com/cpb }\end{array}$ \\
\cline { 2 - 3 } Swn
\end{tabular}}

on MDA-MB-231 cells when sufficiently downregulated; however, opposite outcomes could be observed when miRNAs were upregulated, leading to Notch pathway alteration $[42,43]$. The absence of miR-181a and miR-139-5p were revealed in different cancers such as hepatocellular carcinoma and gastric cancers [44, 45]. However, if these two factors are introduced into breast cancer cells, the ability of invasion and migration could be significantly reduced [ 46 , 47]. In addition, miR-181 has been reported to enhance chemosensitivity in breast cancer treatment. Another critical component that regulates tumor progression is miR34a. Previous data have demonstrated that

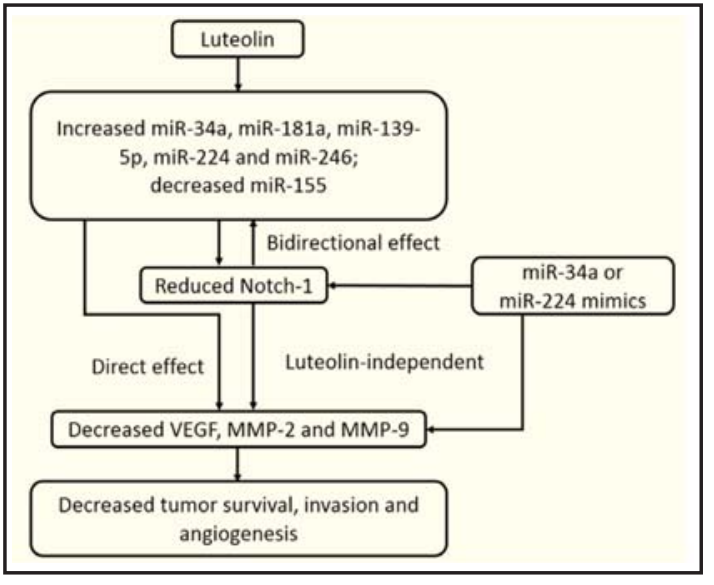

Fig. 13. The complex interaction loop among Luteolin, miRNAs and the Notch pathway is shown.

this miRNA was not identified or was barely detected in different malignancies including neuroblastoma and prostate, bladder and cervical cancers [48-51]. It was also found that Notch-1 and Notch-2 proteins were significantly reduced after miR-34a was introduced in neuroglia cells and pancreatic cancer cells, illustrating that components in the Notch pathway could be downstream factors of miR-34a [12, 52].

Interesting findings in miRNA analyses provided further details in Luteolin and Notch signaling interaction (Fig. 13). Our preliminary data identified increased miR-34a and decreased Notch-1 levels simultaneously after applying Luteolin; thus, further experiments were carried out to illustrate the inhibiting effect of Luteolin on other components in the Notch pathway and miRNAs, as well as their corresponding mechanism. Furthermore, we sought to find out the expression profile of miRNAs in different Luteolin and Notch-1 levels. Our results revealed an increased expression of several barely seen miRNAs in breast cancer cells such as miR-34a, miR-181a, miR-139-5p, miR-224 and miR-246 after the application of Luteolin; while, at the same time, miR-155 levels significantly decreased with the same treatment. Moreover, transfected miR-34a or miR-224 mimics directly led to reduced Notch-1 levels, illustrating that Luteolin inhibited Notch signaling by regulating miRNAs. Nonetheless, according to our study, the interaction between miRNA and Notch-1 is not monodirectional. Notch-1 silencing could also cause decreased miR-155 levels and increased miR-34a, miR181a, miR-139-5p, miR-224 and miR-246 levels, suggesting that downregulated Notch-1 provided inverse signal feedback, and thus, bidirectionally interacted with miRNAs. The introduction of miR-34a or miR-224 mimics also presented negative effects on VEGF, MMP2 and MMP-9 expression levels, which lead to decreased tumor survival, invasion and angiogenesis; indicating that miRNAs could be independent from both Luteolin and Notch signaling, and directly alters cancer development and progression.

In conclusion, this study strongly indicate the fact that Luteolin could significantly inhibit Notch signaling (decreased key components such as Notch-1, Hes-1, VEGF, and MMPs) by regulating miRNAs associated with tumor development and progression (upregulated miR-34a, miR-181a, miR-139-5p, miR-224 and miR-246, as well as downregulated miR155). We have also illustrated the complex interaction loop among Luteolin, miRNAs and the Notch pathway. The effect of miRNAs on Notch-1 could be introduced by Luteolin. However, it may also be Luteolin-independent. MiRNAs led to tumor suppression through Notch signaling, while reduced VEGF and MMPs directly introduced by miRNAs could be alternative explanations. Finally, Notch-1 alteration may inversely change miRNA levels. All above evidences demonstrate the critical status of Luteolin, miRNAs and the Notch pathway, suggesting that any components within the network could be a potential target for future treatment and drug delivery. 


\section{Cellular Physiology Cell Physiol Biochem 2015;37:1693-1711 \begin{tabular}{l|l}
\hline DOI: 10.1159/000438535 & (c) 2015 S. Karger AG, Basel
\end{tabular} \begin{tabular}{l|l} 
and Biochemistry Published online: November 09, 2015 & www.karger.com/cpb \\
\hline
\end{tabular} \\ Sun et al.: Luteolin Regulates Notch Signaling and miRNAs}

\section{Acknowledgments}

This study is supported by the National Natural Science Foundation of China (Grant number: 81272470) and the Natural Science Foundation of Jiangsu Province (Grant number: H201410).

\section{Disclosure Statement}

The authors declare no conflicts of interest in this work.

\section{References}

1 Siegel R, Ma J, Zou Z, Jemal A: Cancer statistics, 2014. CA Cancer J Clin 2014;64:9-29.

2 Beatus P, Lundkvist J, Oberg C, Pedersen K, Lendahl U: The origin of the ankyrin repeat region in notch intracellular domains is critical for regulation of hes promoter activity. Mech Dev 2001;104:3-20.

3 Cantarini MC, de la Monte SM, Pang M, Tong M, D'Errico A, Trevisani F, Wands JR: Aspartyl-asparagyl beta hydroxylase over-expression in human hepatoma is linked to activation of insulin-like growth factor and notch signaling mechanisms. Hepatology 2006;44:446-457.

4 Leong KG, Gao WQ: The notch pathway in prostate development and cancer. Differentiation 2008;76:699716.

5 Maliekal TT, Bajaj J, Giri V, Subramanyam D, Krishna S: The role of notch signaling in human cervical cancer: Implications for solid tumors. Oncogene 2008;27:5110-5114.

6 Westhoff B, Colaluca IN, D'Ario G, Donzelli M, Tosoni D, Volorio S, Pelosi G, Spaggiari L, Mazzarol G, Viale G, Pece S, Di Fiore PP: Alterations of the notch pathway in lung cancer. Proc Natl Acad Sci U S A 2009;106:22293-22298.

7 Hughes DP: How the notch pathway contributes to the ability of osteosarcoma cells to metastasize. Cancer Treat Res 2009;152:479-496.

8 Fre S, Huyghe M, Mourikis P, Robine S, Louvard D, Artavanis-Tsakonas S: Notch signals control the fate of immature progenitor cells in the intestine. Nature 2005;435:964-968.

9 Ohrt T, Merkle D, Birkenfeld K, Echeverri CJ, Schwille P: In situ fluorescence analysis demonstrates active sirna exclusion from the nucleus by exportin 5. Nucleic Acids Res 2006;34:1369-1380.

10 Zhang J, Zhang Hd, Chen L, Sun da W, Mao Cf, Chen W, Wu JZ, Zhong SL, Zhao JH, Tang JH: $\beta$-elemene reverses chemoresistance of breast cancer via regulating MDR-related microRNA expression. Cell Physiol Biochem 2014;34:2027-2037.

11 Wang Z, Li Y, Kong D, Ahmad A, Banerjee S, Sarkar FH: Cross-talk between mirna and notch signaling pathways in tumor development and progression. Cancer Lett 2010;292:141-148.

12 Yamakuchi M, Ferlito M, Lowenstein CJ: Mir-34a repression of sirt1 regulates apoptosis. Proc Natl Acad Sci U S A 2008;105:13421-13426.

13 Pang RT, Leung CO, Ye TM, Liu W, Chiu PC, Lam KK, Lee KF, Yeung WS: Microrna-34a suppresses invasion through downregulation of notch1 and jagged1 in cervical carcinoma and choriocarcinoma cells. Carcinogenesis 2010;31:1037-1044.

14 Seelinger G, Merfort I, Wölfle U, Schempp CM: Anti-carcinogenic effects of the flavonoid luteolin. Molecules 2008;13:2628-2651.

15 Selvendiran K, Koga H, Ueno T, Yoshida T, Maeyama M, Torimura T, Yano H, Kojiro M, Sata M: Luteolin promotes degradation in signal transducer and activator of transcription 3 in human hepatoma cells: An implication for the antitumor potential of flavonoids. Cancer Res 2006;66:4826-4834.

16 Ende C, Gebhardt R: Inhibition of matrix metalloproteinase- 2 and -9 activities by selected flavonoids. Planta Med 2004;70:1006-1008.

17 Vijayababu MR, Arunkumar A, Kanagaraj P, Venkataraman P, Krishnamoorthy G, Arunakaran J: Quercetin downregulates matrix metalloproteinases 2 and 9 proteins expression in prostate cancer cells (pc-3). Mol Cell Biochem 2006;287:109-116. 


\section{Cellular Physiology Cell Physiol Biochem 2015;37:1693-1711

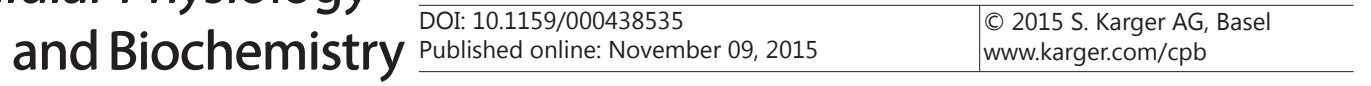 \\ Sun et al.: Luteolin Regulates Notch Signaling and miRNAs}

18 Ruan JS, Liu YP, Zhang L, Yan LG, Fan FT, Shen CS, Wang AY, Zheng SZ, Wang SM, Lu Y: Luteolin reduces the invasive potential of malignant melanoma cells by targeting beta3 integrin and the epithelial-mesenchymal transition. Acta Pharmacol Sin 2012;33:1325-1331.

19 Bao B, Ali S, Banerjee S, Wang Z, Logna F, Azmi AS, Kong D, Ahmad A, Li Y, Padhye S, Sarkar FH: Curcumin analogue cdf inhibits pancreatic tumor growth by switching on suppressor micrornas and attenuating ezh2 expression. Cancer Res 2012;72:335-345.

20 Zhang K, Yao HP, Wang MH: Activation of ron differentially regulates claudin expression and localization: Role of claudin-1 in ron-mediated epithelial cell motility. Carcinogenesis 2008;29:552-559.

21 Li Y, Vandenboom TG, 2nd, Wang Z, Kong D, Ali S, Philip PA, Sarkar FH: Mir-146a suppresses invasion of pancreatic cancer cells. Cancer Res 2010;70:1486-1495.

22 Wang Z, Banerjee S, Kong D, Li Y, Sarkar FH: Down-regulation of forkhead box $\mathrm{m} 1$ transcription factor leads to the inhibition of invasion and angiogenesis of pancreatic cancer cells. Cancer Res 2007;67:82938300.

23 Leow PC, Tian Q Ong ZY, Yang Z, Ee PL: Antitumor activity of natural compounds, curcumin and pkf118310, as wnt/beta-catenin antagonists against human osteosarcoma cells. Invest New Drugs 2010;28:766782.

24 Sweeney TE, Suliman HB, Hollingsworth JW, Piantadosi CA: Differential regulation of the pgc family of genes in a mouse model of staphylococcus aureus sepsis. PLoS One 2010;5:e11606.

25 Harborth J, Elbashir SM, Bechert K, Tuschl T, Weber K: Identification of essential genes in cultured mammalian cells using small interfering rnas. J Cell Sci 2001;114:4557-4565.

26 Li Y, Zhang J, Ma D, Zhang L, Si M, Yin H, Li J: Curcumin inhibits proliferation and invasion of osteosarcoma cells through inactivation of notch-1 signaling. FEBS J 2012;279:2247-2259.

27 Du R, Sun W, Xia L, Zhao A, Yu Y, Zhao L, Wang H, Huang C, Sun S: Hypoxia-induced down-regulation of microrna-34a promotes emt by targeting the notch signaling pathway in tubular epithelial cells. PLoS One 2012;7:e30771.

28 Hsu HF, Houng JY, Chang CL, Wu CC, Chang FR, Wu YC: Antioxidant activity, cytotoxicity, and DNA information of glossogyne tenuifolia. J Agric Food Chem 2005;53:6117-6125.

29 Kotanidou A, Xagorari A, Bagli E, Kitsanta P, Fotsis T, Papapetropoulos A, Roussos C: Luteolin reduces lipopolysaccharide-induced lethal toxicity and expression of proinflammatory molecules in mice. Am J Respir Crit Care Med 2002;165:818-823.

30 Li YC, Hung CF, Yeh FT, Lin JP, Chung JG: Luteolin-inhibited arylamine n-acetyltransferase activity and DNA2-aminofluorene adduct in human and mouse leukemia cells. Food Chem Toxicol 2001;39:641-647.

31 Sadzuka Y, Sugiyama T, Shimoi K, Kinae N, Hirota S: Protective effect of flavonoids on doxorubicin-induced cardiotoxicity. Toxicol Lett 1997;92:1-7.

32 Wharton KA, Johansen KM, Xu T, Artavanis-Tsakonas S: Nucleotide sequence from the neurogenic locus notch implies a gene product that shares homology with proteins containing egf-like repeats. Cell 1985;43:567-581.

33 Babine RE, Bender SL: Molecular recognition of proteinminus signligand complexes: Applications to drug design. Chem Rev 1997;97:1359-1472.

34 Lamy S, Bedard V, Labbe D, Sartelet H, Barthomeuf C, Gingras D, Beliveau R: The dietary flavones apigenin and luteolin impair smooth muscle cell migration and vegf expression through inhibition of pdgfr-beta phosphorylation. Cancer Prev Res (Phila) 2008;1:452-459.

35 Curran S, Murray GI: Matrix metalloproteinases: Molecular aspects of their roles in tumour invasion and metastasis. Eur J Cancer 2000;36:1621-1630.

36 Loges S, Mazzone M, Hohensinner P, Carmeliet P: Silencing or fueling metastasis with vegf inhibitors: Antiangiogenesis revisited. Cancer Cell 2009;15:167-170.

37 Taylor DD, Gercel-Taylor C: Microrna signatures of tumor-derived exosomes as diagnostic biomarkers of ovarian cancer. Gynecol Oncol 2008;110:13-21.

38 Jones KB, Salah Z, Del Mare S, Galasso M, Gaudio E, Nuovo GJ, Lovat F, LeBlanc K, Palatini J, Randall RL, Volinia S, Stein GS, Croce CM, Lian JB, Aqeilan RI: Mirna signatures associate with pathogenesis and progression of osteosarcoma. Cancer Res 2012;72:1865-1877.

39 Kong W, Yang H, He L, Zhao JJ, Coppola D, Dalton WS, Cheng JQ: Microrna-155 is regulated by the transforming growth factor beta/smad pathway and contributes to epithelial cell plasticity by targeting rhoa. Mol Cell Biol 2008;28:6773-6784. 


\section{Cellular Physiology Cell Physiol Biochem 2015;37:1693-1711 \begin{tabular}{ll|l} 
and Biochemistry & $\begin{array}{l}\text { DOI: 10.1159/000438535 } \\
\text { Published online: November 09, } 2015\end{array}$ & $\begin{array}{l}\text { ○ 2015 S. Karger AG, Basel } \\
\text { www.karger.com/cpb }\end{array}$ \\
\hline
\end{tabular} \\ Sun et al.: Luteolin Regulates Notch Signaling and miRNAs}

40 Volinia S, Calin GA, Liu CG, Ambs S, Cimmino A, Petrocca F, Visone R, Iorio M, Roldo C, Ferracin M, Prueitt RL, Yanaihara N, Lanza G, Scarpa A, Vecchione A, Negrini M, Harris CC, Croce CM: A microrna expression signature of human solid tumors defines cancer gene targets. Proc Natl Acad Sci U S A 2006;103:22572261.

41 Yanaihara N, Caplen N, Bowman E, Seike M, Kumamoto K, Yi M, Stephens RM, Okamoto A, Yokota J, Tanaka T, Calin GA, Liu CG, Croce CM, Harris CC: Unique microrna molecular profiles in lung cancer diagnosis and prognosis. Cancer Cell 2006;9:189-198.

42 Wang L, Zhang H, Rodriguez S, Cao L, Parish J, Mumaw C, Zollman A, Kamoka MM, Mu J, Chen DZ, Srour EF, Chitteti BR, HogenEsch H, Tu X, Bellido TM, Boswell HS, Manshouri T, Verstovsek S, Yoder MC, Kapur R, Cardoso AA, Carlesso N: Notch-dependent repression of mir-155 in the bone marrow niche regulates hematopoiesis in an nf-kappab-dependent manner. Cell Stem Cell 2014;15:51-65.

43 Jiang S, Zhang HW, Lu MH, He XH, Li Y, Gu H, Liu MF, Wang ED: Microrna-155 functions as an oncomir in breast cancer by targeting the suppressor of cytokine signaling 1 gene. Cancer Res 2010;70:3119-3127.

44 Guo J, Miao Y, Xiao B, Huan R, Jiang Z, Meng D, Wang Y: Differential expression of microrna species in human gastric cancer versus non-tumorous tissues. J Gastroenterol Hepatol 2009;24:652-657.

45 Ji J, Yamashita T, Budhu A, Forgues M, Jia HL, Li C, Deng C, Wauthier E, Reid LM, Ye QH, Qin LX, Yang W, Wang HY, Tang ZY, Croce CM, Wang XW: Identification of microrna-181 by genome-wide screening as a critical player in epcam-positive hepatic cancer stem cells. Hepatology 2009;50:472-480.

46 Wang Y, Yu Y, Tsuyada A, Ren X, Wu X, Stubblefield K, Rankin-Gee EK, Wang SE: Transforming growth factor-beta regulates the sphere-initiating stem cell-like feature in breast cancer through mirna-181 and atm. Oncogene 2011;30:1470-1480.

47 Wong CC, Wong CM, Tung EK, Au SL, Lee JM, Poon RT, Man K, Ng IO: The microrna mir-139 suppresses metastasis and progression of hepatocellular carcinoma by down-regulating rho-kinase 2 . Gastroenterology 2011;140:322-331.

48 Zhu Y, Wu J, Li S, Ma R, Cao H, Ji M, Jing C, Tang J: The function role of miR-181a in chemosensitivity to adriamycin by targeting Bcl-2 in low-invasive breast cancer cells. Cell Physiol Biochem 2013;32:12251237.

49 Vinall RL, Ripoll AZ, Wang S, Pan CX, deVere White RW: Mir-34a chemosensitizes bladder cancer cells to cisplatin treatment regardless of p53-rb pathway status. Int J Cancer 2012;130:2526-2538.

50 Wang X, Wang HK, McCoy JP, Banerjee NS, Rader JS, Broker TR, Meyers C, Chow LT, Zheng ZM: Oncogenic hpv infection interrupts the expression of tumor-suppressive mir-34a through viral oncoprotein e6. RNA 2009;15:637-647.

51 Welch C, Chen Y, Stallings RL: Microrna-34a functions as a potential tumor suppressor by inducing apoptosis in neuroblastoma cells. Oncogene 2007;26:5017-5022.

52 Ji Q Hao X, Zhang M, Tang W, Yang M, Li L, Xiang D, Desano JT, Bommer GT, Fan D, Fearon ER, Lawrence TS, Xu L: Microrna mir-34 inhibits human pancreatic cancer tumor-initiating cells. PLoS One 2009;4:e6816. 